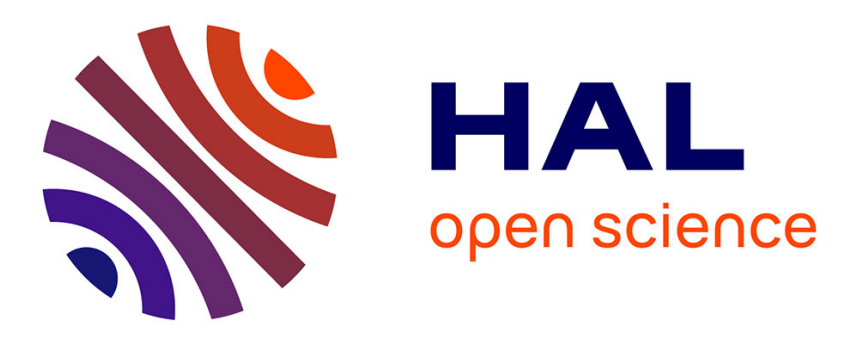

\title{
Application of childhood apraxia of speech clinical markers to French-speaking children: A preliminary study
}

Geneviève Meloni, Valérie Schott-Brua, Anne Vilain, Hélène Lœvenbruck, Eulalies Consortium, Andrea Macleod

\section{To cite this version:}

Geneviève Meloni, Valérie Schott-Brua, Anne Vilain, Hélène Lœvenbruck, Eulalies Consortium, et al.. Application of childhood apraxia of speech clinical markers to French-speaking children: A preliminary study. International Journal of Speech-Language Pathology, 2020, 22 (6), pp.683-695. 10.1080/17549507.2020.1844799 . hal-03344800

\section{HAL Id: hal-03344800 \\ https://hal.univ-grenoble-alpes.fr/hal-03344800}

Submitted on 24 Oct 2021

HAL is a multi-disciplinary open access archive for the deposit and dissemination of scientific research documents, whether they are published or not. The documents may come from teaching and research institutions in France or abroad, or from public or private research centers.
L'archive ouverte pluridisciplinaire HAL, est destinée au dépôt et à la diffusion de documents scientifiques de niveau recherche, publiés ou non, émanant des établissements d'enseignement et de recherche français ou étrangers, des laboratoires publics ou privés. 
Preliminary version produced by the authors.

Geneviève Meloni, Valérie Schott-Brua, Anne Vilain, Hélène Lœvenbruck, Eulalies Consortium*, et al.. Application of childhood apraxia of speech clinical markers to French-speaking children: A preliminary study. International Journal of Speech-Language Pathology, 2020, 22 (6), pp.683-695. 〈10.1080/17549507.2020.1844799〉. 〈hal-03344800〉

*Consortium EULALIES (alphabetical order): Gillet-Perret, E. (CRTLA, CHUGA), Machart, L. (LPNC-GIPSA-lab), Puissant C. (GIPSA-lab)

\title{
Application of Childhood Apraxia of Speech clinical markers to French-speaking children:
}

\section{a preliminary study}

Meloni, Geneviève, Lœvenbruck, Hélène, Vilain, Anne, Gillet-Perret, Estelle, Eulalies Consortium \& MacLeod, Andrea A. N.

\begin{abstract}
:
Purpose: Childhood apraxia of speech (CAS) is difficult to diagnose because there is little agreement on objective clinical markers. Since studies of phonological development in French-speaking children are scarce, there are even fewer recognized markers in French as compared to English. This study aims to determine if a set of operationalized, quantitative measures derived from clinical markers of CAS in English corroborate with clinical CAS diagnosis in French-speaking children. This research contributes to improving differential diagnosis of CAS and phonological disorder cross-linguistically.

Method: We collected data from five children diagnosed with CAS, nine children diagnosed with phonological disorder, and 75 typically-developing children aged 5;10 to 9;2 years old. All children were assessed on three speech production tasks: picture-naming, non-word repetition, and diadochokinesis. We extracted 20 quantitative measures corresponding to commonly accepted clinical features of CAS.
\end{abstract}

Results: Similar to English-speaking children, French-speaking children with CAS exhibited a high number of vowel errors, consonant and cluster errors, consonant epentheses, devoicing errors, slow DDK rate, more inconsistency and increased errors with longer words. Contrary to studies on English, these children with CAS did not produce intrusive schwas or vowels.

Conclusion: This multiple-case study highlights the need for cross-linguistic diagnostic criteria for CAS.

Key words: Assessment, Diagnosis, Childhood Apraxia of Speech, Speech Sound Disorders, Speech and Language Pathologist, French-speaking Children 
Preliminary version produced by the authors.

Geneviève Meloni, Valérie Schott-Brua, Anne Vilain, Hélène Lœvenbruck, Eulalies Consortium*, et al.. Application of childhood apraxia of speech clinical markers to French-speaking children: A preliminary study. International Journal of Speech-Language Pathology, 2020, 22 (6), pp.683-695. 〈10.1080/17549507.2020.1844799〉. 〈hal-03344800〉

*Consortium EULALIES (alphabetical order): Gillet-Perret, E. (CRTLA, CHUGA), Machart, L. (LPNC-GIPSA-lab), Puissant C. (GIPSA-lab)

\section{Introduction}

Children with speech sound disorders (SSD) have difficulties in speech sound development and reduced speech intelligibility (Baker \& McLeod, 2011). SSD are the most common paediatric communication disorder and constitute a large proportion of Speech-Language Pathologists' (SLP) caseloads (Broomfield \& Dodd, 2004). SSD can play an important role in children's long term social and academic success due, in part, to the overlap between the development of speech, language, and reading-writing (Felsenfeld, Broen \& McGue, 1994). Although SSD can be related to identifiable causes (such as hearing impairment or Down syndrome), $60 \%$ of SSD have an unknown etiology (Shriberg et al., 2010) and thus identifying SSD is an essential step in providing clinical services to improve their communication. Accurate identification is particularly challenging for French-speaking clinicians as there is little research on the characteristics of SSD in French. The present study provides an initial overview of potential features for distinguishing between children with typical speech sound development and children with SSD and between subtypes of SSD.

Children with SSD can display a variety of profiles as SSD refers to any combination of difficulties with speech sound perception, with motor production, and/or with phonological representation of speech sounds, phonotactics, and prosody (International Expert Panel on Multilingual Children's Speech, 2012, p.1). Consequently, identifying subtypes of SSD helps clinicians to pinpoint core deficit(s), and to select and implement an appropriate intervention approach. As reviewed by Waring \& Knight (2013), three main types of SSD are identified across different classification systems: an articulation-based subtype, a motor planning or programming subtype, and a phonological subtype. There is no gold standard, however, in labels for SSD subtypes and criteria for diagnosis, making it difficult to establish differential diagnoses and to compare across studies. In addition, research has focused on English-speaking children and thus the extent to which diagnostic criteria apply across languages is unclear. With this in mind, we will provide an overview of the characteristics of two subtypes of SSD: the motor planning-programming subtype, or Childhood Apraxia of Speech (CAS), and a phonological subtype, or Phonological Disorder (PD) (see Appendix A). 
Preliminary version produced by the authors.

Geneviève Meloni, Valérie Schott-Brua, Anne Vilain, Hélène Lœvenbruck, Eulalies Consortium*, et al.. Application of childhood apraxia of speech clinical markers to French-speaking children: A preliminary study. International Journal of Speech-Language Pathology, 2020, 22 (6), pp.683-695. 〈10.1080/17549507.2020.1844799〉. 〈hal-03344800〉

*Consortium EULALIES (alphabetical order): Gillet-Perret, E. (CRTLA, CHUGA), Machart, L. (LPNC-GIPSA-lab), Puissant C. (GIPSA-lab)

Differential diagnosis between children with CAS and PD is very challenging for SLPs for several reasons (Charron, 2015). First, the clinical markers of CAS and PD overlap. For example, low accuracy in producing phonemes is common across both disorders as are frequent phonological errors. Second, these clinical markers also lack consensus due in part to differences in classification frameworks (Waring \& Knight, 2013) and in part to disagreement on which task to use to assess children's speech (Shriberg et al., 2017). Despite these challenges, a strategy has emerged to differentiate between CAS and PD by focusing on the characteristics most commonly observed in CAS, and less frequently observed in children with PD. Some of these characteristics have been grouped into a checklist proposed by Strand (provided in Shriberg et al., 2012), who argues that a diagnosis of CAS should be made if a child presents with vowel distortions plus 3 or more characteristics on the list of 10 markers.

In addition to the challenges outlined above, distinguishing between CAS and PD in French-speaking children has additional challenges: a lack of research on SSD in French-speaking children, and limited normative data and assessment tools. Specifically, there are few studies with normative data that describe typical phonological development and limited standardized, norm-referenced assessment tools. To our knowledge, three studies have investigated phonological development in Québécois-French speaking children (Paul \& Rvachew, 2008; MacLeod et al., 2011; Rvachew et al., 2013) and two studies on France-French-speaking children (Aircart-de Falco \& Vion, 1987; Vinter, 2001). Although these studies are essential for SLPs, they present some limitations: they are mostly based on picture naming of short words, some consonants are not mastered within the age range targeted, and two of these five studies present a very low number of participants (Vinter, 2001, N=13; Paul \& Rvachew, 2008, N=10). Concerning standardized assessment tools, four tasks are available for Québécois French (TFP from Paul \& Rvachew, 2008; ESPP from MacLeod et al., 2014; TDFP from Rvachew et al., 2012; and Test de Phonologie du Français from Bérubé et al., 2015) and eleven tasks are available for France French (for a review see Meloni, 2015). However, these tasks focus on picture naming, have restricted age ranges, and limited psychometric properties. 
Preliminary version produced by the authors.

Geneviève Meloni, Valérie Schott-Brua, Anne Vilain, Hélène Lœvenbruck, Eulalies Consortium*, et al.. Application of childhood apraxia of speech clinical markers to French-speaking children: A preliminary study. International Journal of Speech-Language Pathology, 2020, 22 (6), pp.683-695. 〈10.1080/17549507.2020.1844799〉. 〈hal-03344800〉

*Consortium EULALIES (alphabetical order): Gillet-Perret, E. (CRTLA, CHUGA), Machart, L. (LPNC-GIPSA-lab), Puissant C. (GIPSA-lab)

Second, as we noted above, research on children with SSD has mainly focused on English-speaking children, with a few exceptions (e.g., Québécois French-speaking children with PD: Rvachew \& Brosseau-Lapré, 2015). As a result, it is quite challenging to identify which markers from English are relevant in other languages since differences across phonological systems may limit the applicability of the markers. For example, French differs from English in its inventory of consonants and vowels, its common syllable structures, its phonotactic rules, and its prosody (see Appendix B; MacLeod et al., 2011; Rose \& Wauquier-Gravelines, 2007).

Differences at the word level and phonetic level may also limit the applicability. For example, the frequency of different word lengths differs in French and English, with four-syllable words frequent in the French adult lexicon. Contrary to English, the early lexicon produced and understood by French-speaking children, as identified on the French-language adaptation of the MacArthur Bates Communicative Development Index (Kern, Langue, Zesiger \& Bovet, 2010), has more multisyllabic words than monosyllabic words. It can be expected that frequency of multisyllabic words in the ambient language may influence how multisyllabic sequences are mastered by children. Disproportionate difficulty with multisyllabic word production is one of the markers of CAS in English that may, therefore, be ill-adapted to French, since multisyllabic words are more frequent in the input of French children. There are also phonetic differences in the timing of voicing onset related to stop production. Whereas voiceless stops in syllable onsets are usually aspirated in English, this aspiration is uncommon in most dialects of French (except for some varieties of Canadian French, MacLeod, 2016). Voiced stops in standard French are produced with a long pre-voicing, whereas they are produced with short-lag voicing, or as voiceless unaspirated in English (MacLeod, 2016). In English, replacing voiceless consonants by their voiced cognates, which reduces the delay between closure release and onset of voicing, is a trait of CAS in English (e.g. luzzini-Seigel et al., 2017). Given that pre-voicing is demanding in terms of timing and coordination between the glottis and articulators, it can be expected that insufficient pre-voicing, rather than replacing voiceless with voiced consonants, may be a more common error in Frenchspeaking children. Indeed, voicing is a very rare error pattern in French (between 0 and $2 \%$ of occurrence for children from 24 months to 7 years old, Brosseau-Lapré et al., 2018). Moreover, there are dialectal variations 
Preliminary version produced by the authors.

Geneviève Meloni, Valérie Schott-Brua, Anne Vilain, Hélène Lœvenbruck, Eulalies Consortium*, et al.. Application of childhood apraxia of speech clinical markers to French-speaking children: A preliminary study. International Journal of Speech-Language Pathology, 2020, 22 (6), pp.683-695. 〈10.1080/17549507.2020.1844799〉. 〈hal-03344800〉

*Consortium EULALIES (alphabetical order): Gillet-Perret, E. (CRTLA, CHUGA), Machart, L. (LPNC-GIPSA-lab), Puissant C. (GIPSA-lab)

and utterance length variations that can impact schwa production, while schwa inclusion is currently considered as one of the CAS markers in English. Speakers of France French tend to elide schwas and create more consonant clusters (except speakers from southern France). The speech input of French-acquiring children therefore contains many clusters, and cluster simplification is typically produced by deletion of one segment, rather than by schwa insertion (Brosseau-Lapré et al., 2018).

Taken together, the lack of data on SSD in French-speaking children and limited normative data and assessment tools may explain why only $5 \%$ of French SLPs are confident in their diagnostic of CAS, and $30 \%$ are moderately confident (Masson, 2017). Diagnostic criteria are highly variable across clinicians (Forrest, 2003; Masson, 2017) and may include, but are not limited to, very poor intelligibility, persistence of speech difficulties despite intervention, error patterns specific to motor speech difficulties such as slow articulation rate, groping, intrusive pauses, and clinical impression.

\section{Current Study}

The research reviewed above highlighted the difficulty in differentiating between children with CAS and PD, and the particular challenge faced when working with French-speaking children. We will focus on two questions. First, do the English markers of CAS correspond to the clinical impression of French SLPs? We hypothesize that a subset of clinical markers from English will be also found in French, such as vowel and consonant errors or slow diadochokinetic rate, but other markers will not. In particular, we expect the following three markers to be less relevant for French-speaking children: (1) word length would be less likely to impact phoneme accuracy as they are more used to producing bi- or polysyllabic words; (2) voiceless consonants would be less likely to be replaced with voiced cognates, as pre-voicing is more demanding in terms of timing and coordination between the glottis and articulators; and (3) intrusive schwas would not be a common error pattern of cluster simplification, since schwa elision is frequent in the dialects of French studied, and cluster reduction is typically produced by omission of one segment rather than schwa insertion. 
Preliminary version produced by the authors.

Geneviève Meloni, Valérie Schott-Brua, Anne Vilain, Hélène Lœvenbruck, Eulalies Consortium*, et al.. Application of childhood apraxia of speech clinical markers to French-speaking children: A preliminary study. International Journal of Speech-Language Pathology, 2020, 22 (6), pp.683-695. 〈10.1080/17549507.2020.1844799〉. 〈hal-03344800〉

*Consortium EULALIES (alphabetical order): Gillet-Perret, E. (CRTLA, CHUGA), Machart, L. (LPNC-GIPSA-lab), Puissant C. (GIPSA-lab)

Our second research question aims at assessing whether these markers help to distinguish between Frenchspeaking children with CAS, phonological disorder, and typical development. This question is explored within the broader framework of the France-Canada project, EULALIES, which has three aims: to develop an assessment protocol that will be used to diagnose children with SSD who speak French; to provide reference data on typical development; and to develop clinical markers for French-speaking children with SSD. Our assessment protocol is based on a hierarchical view of speech processing (e.g. Van der Merwe, 2009, Terband, Maassen \& Maas, 2019). In this view, after grammatical encoding and lexicon retrieval, speech production involves the following hierarchical processing levels: phonological encoding, motor planning, motor programming, and motor execution. Our protocol includes five different tasks assessing perception and production of speech. In the present study, we focus on EULALIES' third aim, i.e. identifying clinical markers, and we concentrate on three production tasks, that mainly target four hierarchical levels. First, the picture-naming task evaluates the retrieval of lexical representations stored in long-term memory as well as phonological encoding and downstream processes. Second, the non-word repetition task tests speech perception and production processes as a whole but more specifically challenges phonological encoding and motor planning. Finally, the diadochokinetic task targets motor planning and motor programming. Based on working definitions of subtypes of SSD, we hypothesize that these three tasks could help in the differential diagnosis between children with SSD and typically-developing children and between children with CAS and PD. We propose that PD is associated with impairment or weakness in high level phonological representations and that CAS is related to an impairment or weakness in motor planning and programming.

\section{Method}

The present study was conducted in two major cities in France: Grenoble and Lyon, in the Rhône-Alpes region, which is not part of the southern France-French dialect region. The study was approved by the local ethics review board (CERNI N²014-11-18-54 and CER Grenoble Alpes- 2018-04-03-2). For all participants, parents or caregivers provided informed consent on behalf of the children. 
Preliminary version produced by the authors.

Geneviève Meloni, Valérie Schott-Brua, Anne Vilain, Hélène Lœvenbruck, Eulalies Consortium*, et al.. Application of childhood apraxia of speech clinical markers to French-speaking children: A preliminary study. International Journal of Speech-Language Pathology, 2020, 22 (6), pp.683-695. 〈10.1080/17549507.2020.1844799〉. 〈hal-03344800〉

*Consortium EULALIES (alphabetical order): Gillet-Perret, E. (CRTLA, CHUGA), Machart, L. (LPNC-GIPSA-lab), Puissant C. (GIPSA-lab)

\section{Participants}

The participants in this study were placed in one of two groups: one group of typically-developing children (TYP), and one group of children with SSD, particularly PD and CAS. In total, the TYP group was composed of 75 children ( 41 girls and 34 boys) and the average age was 7;2 years old (SD = 8.82 months). Thirty children in the TYP group were multilingual (40\%). Due to technical issues, only 56 children have completed the nonword repetition task ( 30 girls and 26 boys, 18 multilinguals $=32 \%$, age mean $=7 ; 2$ years old, $S D=10.07$ months). The SSD group was composed of 14 children ( 4 girls and 10 boys) and the average age was 7;5 years old ( $S D=10.67$ months). Five children had been diagnosed with severe CAS (all monolinguals), and nine with severe PD (8 monolinguals). We recruited TYP children in public and private schools. For children with SSD, we contacted SLPs of the Rhône-Alpes region, via email and telephone. For all participants, inclusion criteria were (a) age between 5;6 and 9;6 years old, (b) normal or adjusted-to-normal hearing and vision, (c) ability to understand and hold a conversation in French (bilingual and multilingual children were recruited, provided that they could hold a conversation in French and were enrolled in a French school), and (d) no diagnosed developmental disabilities (e.g., intellectual disability, autism, cerebral palsy). For the SSD group, we added the criterion: (e) a clinical diagnosis of SSD or suspected SSD (only CAS and PD). The first author responded to all inquiries to participate in the study and made sure to exclude children with SSD associated with a developmental disorder and to validate CAS or PD diagnosis based on her clinical experience and perceptual judgment. Children with SSD were all receiving speech-language pathology intervention.

\section{Questionnaire}

Parents of the participants completed a questionnaire to obtain background information. Parents provided their occupation, which we then converted into a code indicating socioeconomic status based on the French national statistical institute, INSEE. Parents were asked if their child had received, or was receiving speechlanguage pathology intervention, audiology intervention, and optometry intervention before or during this 
Preliminary version produced by the authors.

Geneviève Meloni, Valérie Schott-Brua, Anne Vilain, Hélène Lœvenbruck, Eulalies Consortium*, et al.. Application of childhood apraxia of speech clinical markers to French-speaking children: A preliminary study. International Journal of Speech-Language Pathology, 2020, 22 (6), pp.683-695. 〈10.1080/17549507.2020.1844799〉. 〈hal-03344800〉

*Consortium EULALIES (alphabetical order): Gillet-Perret, E. (CRTLA, CHUGA), Machart, L. (LPNC-GIPSA-lab), Puissant C. (GIPSA-lab)

study. Finally, parents were asked to describe their language use at home. These questions were based on two questionnaires: the Alberta Language Development Questionnaire (Paradis, Emmerzael, Sorenson \& Duncan, 2010), and the C-QUEB questionnaire (MacLeod, unpublished). We asked when their child had first been in contact with French, if their child could understand/speak other languages and with whom the child used these other languages. These questions provided us with information about whether the children used language(s) other than French, and how often (daily, weekly, and occasional). Information about socioeconomic status, language use, and contact with French are provided in Appendix C.

\section{Tasks}

The protocol included six tasks, in the same order: three were inclusion tasks, and three were part of the speech assessment. The order was carefully planned to maintain the children's interest, with minor changes allowed to avoid child fatigability. To be included in the study, TYP children had to score within the normal range on the inclusion tasks. Children with SSD only completed the speech assessment tasks. They were not reported as presenting a hearing deficit by the SLT.

The inclusion tasks were the following.

(1) A morphosyntactic task (Production d'énoncés, Evaluation du Langage Oral, Khomsi, 2001) was used to assess the ability to produce morphosyntactic features, in completing 25 sentences with picture support and carrier sentences.

(2) A digit span test (Outil de DÉpistage des DYSlexies, Jacquier-Roux et al., 2005) was used to assess short term verbal memory by measuring the maximum number of digits the child could repeat.

(3) Hearing screening was conducted using a pure-tone audiometric screening test (i.e., $125 \mathrm{~Hz}, 500 \mathrm{~Hz}$, $1000 \mathrm{~Hz}, 2000 \mathrm{~Hz}, 4000 \mathrm{~Hz}$, and $8000 \mathrm{~Hz}$ with $20 \mathrm{~dB}$ intensity). Normal hearing sensitivity was defined as bilaterally symmetrical thresholds of $\leq 20 \mathrm{~dB} \mathrm{HL}$ at all test frequencies between 500 and $4000 \mathrm{~Hz}$.

The speech assessment tasks were: 
Preliminary version produced by the authors.

Geneviève Meloni, Valérie Schott-Brua, Anne Vilain, Hélène Lœvenbruck, Eulalies Consortium*, et al.. Application of childhood apraxia of speech clinical markers to French-speaking children: A preliminary study. International Journal of Speech-Language Pathology, 2020, 22 (6), pp.683-695. 〈10.1080/17549507.2020.1844799〉. 〈hal-03344800〉

*Consortium EULALIES (alphabetical order): Gillet-Perret, E. (CRTLA, CHUGA), Machart, L. (LPNC-GIPSA-lab), Puissant C. (GIPSA-lab)

(4) A diadochokinetic task (DDK) requiring children to rapidly repeat a series of syllables. We asked children to repeat a [pataka] sequence as fast as possible in ten seconds. (NB: One of the children with CAS refused to perform this task). Children were first asked to repeat the targeted syllables [pa], [ta], and [ka], then we provided a small trial by asking children to repeat two sequences [pataka-pataka]. During the task, children were able to keep track of time on the laptop screen displaying a rectangle gradually filling with blue. Children began at a standardized start signal ("one, two, three, go!") and finished at the "stop" signal.

(5) A non-word repetition task (NWR), with 16 items which are different in length (two to four syllables), in word-likeness (some items include a lexical morpheme), in phonotactic frequency (some have a combination of frequent biphones and some infrequent biphones) and in syllabic complexity (with or without clusters). For this task, the sample is four children with CAS, five children with PD, and 56 TYP children. Pre-recorded nonwords were presented one by one, together with an illustration of a cute monster. The children listened to the nonwords via headphones at a comfortable hearing level and were asked to repeat the name of the cute monster displayed on the laptop screen.

(6) A picture-naming task (PN) comprising 68 items, with consonants of French occurring in word initial, word-medial and word-final position, and in syllable-initial, syllable-final, and consonant clusters. In particular, this task included 25 polysyllabic words with three or four syllables.

\section{Procedure}

The TYP children were assessed in a quiet room in their school during school hours by a graduate SLP student and trained graduate or undergraduate students in linguistics. Children with SSD were assessed at home or in the SLPs' clinic where they received treatment. The children with SSD were assessed by one of four trained SLPs involved in this research. On average, the assessment procedure took 40 minutes to complete. For children with SSD, the procedure was divided into two periods of 20 minutes, each one week apart. The children sat in front of a laptop screen on which pictures were displayed. The audio stimuli were presented 
Preliminary version produced by the authors.

Geneviève Meloni, Valérie Schott-Brua, Anne Vilain, Hélène Lœvenbruck, Eulalies Consortium*, et al.. Application of childhood apraxia of speech clinical markers to French-speaking children: A preliminary study. International Journal of Speech-Language Pathology, 2020, 22 (6), pp.683-695. 〈10.1080/17549507.2020.1844799〉. 〈hal-03344800〉

*Consortium EULALIES (alphabetical order): Gillet-Perret, E. (CRTLA, CHUGA), Machart, L. (LPNC-GIPSA-lab), Puissant C. (GIPSA-lab)

via headphones. The assessment battery was audio-recorded using Marantz PMD660 with an AKG C520 headset microphone at $5 \mathrm{~cm}$ mouth-to-microphone distance.

\section{Transcriptions and reliability}

The NWR and the PN tasks were transcribed using a narrow transcription with PHON software (Hedlund \& Rose, 2019). Narrow transcription includes fine-grained phonetic information with diacritics and refinements. Research assistants were trained to adequately follow the transcription protocol. The annotations used the International Phonetic Alphabet and diacritics to code distortions. Our transcription protocol was carefully designed after discussing an initial transcription of a subset of the data until a consensus was reached between the authors and the transcribers. Transcription methods and criteria were then adapted for further annotation. Finally, subsets of data were fully annotated by one transcriber each, and the resulting transcriptions were double-checked by a second transcriber.

The DDK productions were manually segmented and annotated on Praat (Boersma \& Weenink, 2015): on an interval tier, we segmented each [pataka] sequence, and on a second interval tier, we indicated how many syllables were correct per sequence. All transcriptions were validated by a second transcriber and $15 \%$ of the sample was transcribed by a second transcriber and validated by a third transcriber.

\section{Measures}

We selected eight clinical markers among commonly used markers for CAS in English-speaking children (Shriberg et al., 2012). These markers were vowel or consonant errors, intrusive schwas, and vowel epentheses, consonant epentheses, consonant cluster errors, voicing errors, diadochokinetic rate, inconsistency, and word length effect. We examined 20 operationalized measures, mainly extracted with PHON (Hedlund \& Rose, 2020), corresponding to the eight markers: number of errors (i.e. number of phonemes substituted, deleted, and epenthesized) on consonants/vowels/clusters per item in each task (PN and NWR), number of syllable repetitions in ten seconds in DDK, mean number of consonant/schwa/vowel 
Preliminary version produced by the authors.

Geneviève Meloni, Valérie Schott-Brua, Anne Vilain, Hélène Lœvenbruck, Eulalies Consortium*, et al.. Application of childhood apraxia of speech clinical markers to French-speaking children: A preliminary study. International Journal of Speech-Language Pathology, 2020, 22 (6), pp.683-695. 〈10.1080/17549507.2020.1844799〉. 〈hal-03344800〉

*Consortium EULALIES (alphabetical order): Gillet-Perret, E. (CRTLA, CHUGA), Machart, L. (LPNC-GIPSA-lab), Puissant C. (GIPSA-lab)

epentheses per item in each task, mean number of voicing and devoicing errors per item, number or consonant errors per item as a function of item length. Based on luzzini-Seigel et al. (2017), inconsistency score was measured at phonemic level with this formula: $\Sigma$ ( (number of different error types -1 for each phoneme) $/ \Sigma$ (total number of target opportunities) $)$. We chose to focus on the mean number of errors per item rather than on the percentage of errors, as the children produced the same target words and nonwords, and percentage correct can mask word length effects (e.g. 50\% percent phonemes correct may mean two errors in a four-phoneme word or five errors in a ten-phoneme word).

\section{Statistical Analyses}

All graphs and statistical analyses were completed using the R software (R Development Core Team, 2012). We used mixed-effect linear models (Ime function in n/me package) with diagnosis and chronological age in months and their interaction as fixed-effect factors, and subject as random-effect factor when the data were repeated measurements, and linear models when there was only one measure per child. Given the small number of participants in our SSD groups, to make sure that no participant was too influential, we checked that Cook distances remained above an acceptable threshold. The best-fitting model was selected by comparing nested models with the anova function. Then we ran two-tailed multiple comparison tests, using the emmeans function with Tukey adjustment (emmeans package), and Pearson correlation tests. For the sake of clarity, we will not report all the post-hoc analyses on the effect of age on our data, as the effect was similar for all measures: each time the best-fitting model includes age, we observe a decrease in error rate with age for the TYP group. This effect is generally not found in the other two groups, either because there is no decrease in the group, or because of the small number of participants in these two groups.

Results

The results are discussed below for each category.

\section{(1) Vowel and consonant errors}


Preliminary version produced by the authors.

Geneviève Meloni, Valérie Schott-Brua, Anne Vilain, Hélène Lœvenbruck, Eulalies Consortium*, et al.. Application of childhood apraxia of speech clinical markers to French-speaking children: A preliminary study. International Journal of Speech-Language Pathology, 2020, 22 (6), pp.683-695. 〈10.1080/17549507.2020.1844799〉. 〈hal-03344800〉

*Consortium EULALIES (alphabetical order): Gillet-Perret, E. (CRTLA, CHUGA), Machart, L. (LPNC-GIPSA-lab), Puissant C. (GIPSA-lab)

Figure $1 \mathrm{~A}$ and $1 \mathrm{~B}$ displays the mean number of errors per word on consonants and vowels for the $\mathrm{PN}$ and NWR tasks. For PN, the best-fitting linear mixed model includes group and age, with no interaction effect. Multiple comparisons reveal that children with CAS have higher numbers of consonant errors than children with PD ( $p=.002)$ who produced more consonant errors than children with typical development $(p<.001)$. For NWR, the pattern of results is similar: the best-fitting model includes group, age, and their interaction. Children presenting CAS produced more errors on consonants than children with PD $(p=.036)$ and the two groups with SSD produced more errors than TYP children $(p<.001)$. These results are consistent with the literature regarding consonant and vowel errors/distortions as clinical markers of CAS.

Regarding vowel errors, results slightly differ from consonant errors. On the PN task, the best-fitting model only includes group, with no effect of age. Multiple comparisons indicate that TYP children produced fewer vowel errors than the CAS group $(p<.001)$ and the PD group $(p<.001)$, and the difference between CAS and PD children is close to significance $(p=.05)$. In sum, vowel errors seem to be a clinical feature for SSD, but they fail to distinguish between the PD and CAS groups in the PN task. Interestingly, in the non-word repetition task, this clinical marker does seem to distinguish between diagnoses. For NWR, the best-fitting model includes group, age, and their interaction. Multiple comparisons indicate that the CAS group produced more errors than the PD $(p=.002)$ and TYP $(p<.001)$ groups, but that the PD and TYP groups do not differ from each other. In this case, vowel errors on NWR could be a marker to identify the CAS group.

\section{(2) Intrusive schwas and vowel epentheses}

Overall, the number of schwa epentheses is very low. It seems that all groups produced very few tokens of schwa epenthesis. (e.g. mean number of occurrences $=0.75$ per child for the CAS group in the 68 items of the PN task, 0.5 in the 16 items of the NWR task). In order to complement this finding, we looked for vowel epentheses and found them to be similarly infrequent (e.g. mean number of occurrences $=2.4$ per child for the CAS group in the 68 items of the PN task, 1.25 in the 16 items of the NWR task). 
Preliminary version produced by the authors.

Geneviève Meloni, Valérie Schott-Brua, Anne Vilain, Hélène Lœvenbruck, Eulalies Consortium*, et al.. Application of childhood apraxia of speech clinical markers to French-speaking children: A preliminary study. International Journal of Speech-Language Pathology, 2020, 22 (6), pp.683-695. 〈10.1080/17549507.2020.1844799〉. 〈hal-03344800〉

*Consortium EULALIES (alphabetical order): Gillet-Perret, E. (CRTLA, CHUGA), Machart, L. (LPNC-GIPSA-lab), Puissant C. (GIPSA-lab)

\section{(3) Consonant epentheses}

While there is a very low number of vowel epentheses, consonant epentheses were more common (Figure 2A). For real word production, the best-fitting model includes group, age, and their interaction. Multiple comparisons indicate that the CAS group produced epentheses more frequently than the PD group $(p<.001)$ of the TYP group $(p<.001)$, and that the PD group produced more epentheses than TYP children $(p<.001)$. For non-word repetition, results display a different pattern in which PD and CAS groups do not differ. There is a significant effect of diagnosis group, age, and their interaction. Multiple comparisons indicate a significant difference between CAS and TYP children $(p<.001)$ and between PD and TYP children $(p<.001)$ but the difference between CAS and PD children is not significant. This finding suggests that children with CAS may frequently produce consonant epenthesis, even for real and frequent words while PD children mainly do so for non-words.

\section{(4) Consonant cluster errors}

As children presenting CAS tend to have difficulties in preserving word structure, we looked at errors on consonant clusters. For PN, our results (Figure 2B) indicate an effect of diagnostic group, age, and no interaction between age and group. All three groups of participants differ from each other, with children with CAS producing more errors on clusters than children with PD $(p=.003)$, who produce more errors than the TYP group ( $p<.001)$. For NWR, there is an effect of diagnosis group, age, and a significant interaction between age and diagnosis. The CAS and PD groups are similar, and they both differ from the TYP group ( $p<.001$ in both cases). These results suggest that, even with lexical information, children with CAS tend to produce more cluster errors than PD and TYP children.

\section{(5) Voicing errors}

We studied voicing errors in our three groups. Figure $3 \mathrm{~A}$ and Figure $3 \mathrm{~B}$ shows the number of prevoicing (replacing a voiceless consonant with a voiced cognate, i.e. anticipating voice onset) and devoicing (replacing 
Preliminary version produced by the authors.

Geneviève Meloni, Valérie Schott-Brua, Anne Vilain, Hélène Lœvenbruck, Eulalies Consortium*, et al.. Application of childhood apraxia of speech clinical markers to French-speaking children: A preliminary study. International Journal of Speech-Language Pathology, 2020, 22 (6), pp.683-695. 〈10.1080/17549507.2020.1844799〉. 〈hal-03344800〉

*Consortium EULALIES (alphabetical order): Gillet-Perret, E. (CRTLA, CHUGA), Machart, L. (LPNC-GIPSA-lab), Puissant C. (GIPSA-lab)

a voiced consonant with a voiceless cognate, i.e. suppressing prevoicing) errors. The number of devoicing errors in PN is explained by diagnosis group, age, and their interaction. The CAS and PD groups produce more errors than the TYP group ( $p<.001$ in both cases), but they do not differ from each other. In NWR, the explaining factors are diagnosis group and age. Children with CAS produced more errors than children with PD ( $p=.01)$, who produced more errors than children with typical development $(p=.03)$.

Contrary to what was found for devoicing errors, TYP children almost never produced a prevoicing error, but these were sometimes observed for both the CAS and the PD groups. The results show an effect of diagnosis group only for the PN task, and an effect of diagnosis group, age, and their interaction for the NWR task. For prevoicing errors in PN, multiple comparisons reveal a difference between the CAS and TYP groups ( $p<.001)$ and between the PD and TYP groups $(p<.001)$ but no difference between the two groups of children with SSD. However, for the NWR task, there is a significant difference between the CAS and PD groups ( $p=.005)$, while the PD and TYP groups have similar error rates ( $p>$.05). Even though we observed significant differences, the total number of prevoicing errors is very low (with a mean number of 1.6 occurrences per child for the CAS group in the 68 items of the PN task, as opposed to the 13.4 occurrences of devoicing errors for the same group in the same task).

\section{(6) Diadochokinetic rate}

For the diadochokinetic task (Figure 4A), the linear model indicates a diagnosis group effect, but no effect of age. Further statistical tests on the difference between groups show that there is no significant difference between children with PD and TYP children, but a significant difference between children with CAS and TYP children ( $p=.04)$. These results suggest that children with CAS can be distinguished from TYP children on the DDK task, whereas children with PD cannot.

\section{(7) Inconsistency}

For the inconsistency score (Figure 4B), the linear model analyses on the PN task reveal a main effect of diagnostic group and age. Children with CAS and PD have similar inconsistency scores, but the two groups 
Preliminary version produced by the authors.

Geneviève Meloni, Valérie Schott-Brua, Anne Vilain, Hélène Lœvenbruck, Eulalies Consortium*, et al.. Application of childhood apraxia of speech clinical markers to French-speaking children: A preliminary study. International Journal of Speech-Language Pathology, 2020, 22 (6), pp.683-695. 〈10.1080/17549507.2020.1844799〉. 〈hal-03344800〉

*Consortium EULALIES (alphabetical order): Gillet-Perret, E. (CRTLA, CHUGA), Machart, L. (LPNC-GIPSA-lab), Puissant C. (GIPSA-lab)

are significantly less consistent than TYP children for real word production ( $p<.001$ in both cases). For NWR, there is also a main effect of diagnostic and age. For that task, the CAS group is significantly more inconsistent than the PD group $(p=.04)$, and both are more inconsistent than TYP children $(p<.001$ in both cases).

\section{(8) Word Length effect}

Finally, we examined the impact of word length on consonant errors (Appendix C). For the PN task, we tested the differences between diagnostic groups with regards to the number of syllables in the target word. We found that the CAS and PD groups produced more errors than the TYP group for all syllable lengths of the real words, from one to four syllables $(p<.001)$. The CAS group has similar scores to the PD group for oneand two-syllable words, but it has higher error numbers for three- and four-syllable words $(p<.001$ and $p=.02$ respectively). The CAS group also has higher error rates than the PD group for two- and four-syllable nonwords ( $p=.01$ and $p=.046$ respectively).

\section{Discussion}

The purpose of the current study was to examine features of subtypes of SSD in French-speaking children. Currently, there is no consensus regarding diagnostic protocol or clinical markers that differentiate CAS from PD (Shriberg et al., 2017; Murray et al., 2015), but rather SLPs provide diagnosis based on their application of available markers and their expert judgment on speech behaviour. There are only a few descriptions of SSD speech behaviour in French (see e.g. Brosseau-Lapré \& Rvachew, 2017 on Québécois French-speaking children with PD). Our study explored whether clinical markers available in English would be observed in French-speaking children. We hypothesized that the majority of described clinical markers would be found in French, such as vowel and consonant distortions and substitutions, or slow diadochokinetic rate. However, we hypothesized that some markers are more specific to English and would not be found in our sample, such as intrusive schwas, voicing errors, length effects. Children were assessed on three tasks evaluating speech 
Preliminary version produced by the authors.

Geneviève Meloni, Valérie Schott-Brua, Anne Vilain, Hélène Lœvenbruck, Eulalies Consortium*, et al.. Application of childhood apraxia of speech clinical markers to French-speaking children: A preliminary study. International Journal of Speech-Language Pathology, 2020, 22 (6), pp.683-695. 〈10.1080/17549507.2020.1844799〉. 〈hal-03344800〉

*Consortium EULALIES (alphabetical order): Gillet-Perret, E. (CRTLA, CHUGA), Machart, L. (LPNC-GIPSA-lab), Puissant C. (GIPSA-lab)

production: a picture-naming task, a non-word repetition task, and a diadochokinetic task. From these three tasks, we extracted 20 quantitative measures corresponding to potential clinical features of CAS. The statistical analyses examined whether the CAS group differed from peers with PD, and TYP peers. Our study brings to light three main results: (1) two markers, diadochokinetic rate and vowel errors in non-word repetition, differentiated children with CAS; (2) some markers tended to indicate a severity gradient for distinguishing children with typical development from children with PD and children with CAS; and (3) several features and measures seemed to be irrelevant for French-speaking children.

\section{Marker that differentiated children with CAS}

In our study, the two markers that differentiated the CAS group from both the TYP and the PD groups were diadochokinetic rate (i.e. the number of syllables from a [pataka] sequence the children were able to repeat in ten seconds) and vowel errors in non-word repetition. Children with PD performed in the range of TYP children while children with CAS had a slower rate. Slow DDK rate is frequently described as a clinical marker for English-speaking children with CAS. Bernthal, Bankson \& Flipsen (2009) indicate that rapid successive movements involved in DDK are a major problem for children with CAS. Murray et al. (2015) have found that performance at the DDK task is one of the four markers (with syllable segregation, stress matches, and polysyllabic production) that identify children with CAS with 91\% accuracy. Ozanne (2005) also found that children with slow DDK rate, poor sequencing in DDK, and poor nonverbal oral-motor abilities form a cluster of children with motor programming difficulties. DDK rate is associated with motor programming and suggests that children with CAS struggle in specifying timing and force parameters of the motor plan. However, according to Icht \& Ben-David (2014), DDK rate is a language-specific marker, as articulation rate is influenced by one's speaking community, and as segment coarticulation varies across language. The authors stress the importance of setting language-sensitive norms for DDK rate. The present study suggests that for French-speaking participants, DDK rate does seem to be a relevant marker for identifying CAS, as has also been observed for English-speaking children. 
Preliminary version produced by the authors.

Geneviève Meloni, Valérie Schott-Brua, Anne Vilain, Hélène Lœvenbruck, Eulalies Consortium*, et al.. Application of childhood apraxia of speech clinical markers to French-speaking children: A preliminary study. International Journal of Speech-Language Pathology, 2020, 22 (6), pp.683-695. 〈10.1080/17549507.2020.1844799〉. 〈hal-03344800〉

*Consortium EULALIES (alphabetical order): Gillet-Perret, E. (CRTLA, CHUGA), Machart, L. (LPNC-GIPSA-lab), Puissant C. (GIPSA-lab)

The second marker that differentiates children presenting CAS and both the PD and TYP groups is the number of vowel errors in NWR. Vowel distortions have been reported as a potential diagnostic feature of CAS (ASHA, 2007). CAS can be viewed as a difficulty to transform an abstract code into motor speech commands which impact fine-grained phonetic characteristics required for vowel production. In our sample, vowel distortions differentiated the CAS and PD groups, but mostly for the NWR task. There is less difference between the CAS and PD groups for the PN task. Perhaps, children with CAS can use their growing lexical knowledge to support phonological encoding and downstream processes such as motor planning and programming, but when faced with non-words, developing new adapted motor plans and programs may be too challenging, resulting in lower phoneme accuracy.

\section{Markers that seem to be a gradient of severity}

In our sample, some markers were present for all participants, but along a continuum of severity: less severe for TYP children, somewhat more severe for children with PD, and most severe for children with CAS. These markers comprise the majority of the measures that we studied: number of consonant errors, consonant epentheses on picture-naming, cluster errors on picture-naming, length effect on picture-naming, and inconsistency ratio on non-word repetition. We were surprised to find that inconsistency did not stand out as a marker of CAS (Forrest, 2003; ASHA, 2007; luzzini-Seigel et al., 2017), but rather fell along a continuum across the groups; however, this observation is consistent with other researchers (i.e., Murray et al., 2015 and Strand's checklist). Concerning length effect, as French has more bi- and poly-syllabic words than English, we expected that French-speaking children would be less affected by word length (SavinainenMakkonen, 2000). Yet we found that all participants struggled with accurately producing polysyllabic words, but the differences between the three groups increased with word length. Specifically, the CAS group had higher error rates than the PD group for three- and four-syllable words, and for two- and four-syllable nonwords. Clinically, these measures may serve as criterion-referenced measures, rather than clinical markers of CAS. 
Preliminary version produced by the authors.

Geneviève Meloni, Valérie Schott-Brua, Anne Vilain, Hélène Lœvenbruck, Eulalies Consortium*, et al.. Application of childhood apraxia of speech clinical markers to French-speaking children: A preliminary study. International Journal of Speech-Language Pathology, 2020, 22 (6), pp.683-695. 〈10.1080/17549507.2020.1844799〉. 〈hal-03344800〉

*Consortium EULALIES (alphabetical order): Gillet-Perret, E. (CRTLA, CHUGA), Machart, L. (LPNC-GIPSA-lab), Puissant C. (GIPSA-lab)

\section{Markers that do not seem to be relevant for French-speaking children}

Contrary to what is usually described in English-speaking children with CAS, we observed very few tokens of schwa intrusion, vowel epentheses, or prevoicing errors. One explanation for the scarcity of schwa or vowel epentheses or prevoicing errors might be the small number of participants. Due to the very low prevalence of CAS and lack of confidence in diagnosis, recruiting participants was challenging. Another explanation might be language differences as proposed by Wong et al. (2020). Intrusive schwa is a segmental feature in Strand's 10-point checklist (Shriberg et al., 2012) and it is defined by a mid-central vowel appearing inside clusters. In our sample, the number of intrusive schwas was close to zero for children with SSD but also for children with typical development. We further examined vowel epentheses to identify if French-speaking children would use other intrusive vowels. Again, children, with SSD or with TYP, produced very few vowel epentheses. From these results, it seems that French-speaking children do not use this strategy to facilitate cluster production or word onsets. Data available on French phonological development indicate that typically-developing children tend to simplify clusters by deleting one of the consonants in the cluster. This phonological pattern is highly frequent for children between 24 and 29 months (around $30 \%$ of the possible contexts, Brosseau-Lapré et al., 2018). Alternatively, the lack of intrusive schwas could be due to the high variability in schwa production across French dialects where schwa is an optional vowel (Rose \& Wauquier, 2007). Schwa realization (or non-realization) depends on factors such as segmental and suprasegmental structure or dialectal variation. In standard (non-southern France) French, many schwa deletions are observed and cluster simplification is achieved by segment deletion rather than schwa or vowel intrusion. The SSD children in this study seem to behave similarly. For these reasons, the marker "intrusive schwas" might not be a good marker to identify difficulties in segment coarticulation. The third feature that did not seem to apply to French-speaking children was prevoicing errors, which were rare in SSD children. In French, voiced stops are produced with pre-voicing, which requires a dissociation between laryngeal and supralaryngeal control, whereas, in voiceless stops, voice onset can be launched together with closure 
Preliminary version produced by the authors.

Geneviève Meloni, Valérie Schott-Brua, Anne Vilain, Hélène Lœvenbruck, Eulalies Consortium*, et al.. Application of childhood apraxia of speech clinical markers to French-speaking children: A preliminary study. International Journal of Speech-Language Pathology, 2020, 22 (6), pp.683-695. 〈10.1080/17549507.2020.1844799〉. 〈hal-03344800〉

*Consortium EULALIES (alphabetical order): Gillet-Perret, E. (CRTLA, CHUGA), Machart, L. (LPNC-GIPSA-lab), Puissant C. (GIPSA-lab)

release. In English, voiced stops can be produced with roughly simultaneous voice onset and closure release, whereas voiceless stops require separate laryngeal control, with vocal fold vibration held after closure release, during aspiration (MacLeod, 2016). Voiced stops in French may therefore require greater motor programming skills than their voiceless counterparts. In typically-developing children, voiced stop consonants develop at a slower rate than voiceless stops in French (MacLeod et al., 2011) and exhibit more immature acoustic features than their voiceless counterparts (MacLeod, 2016). Thus replacing a voiceless consonant with a voiced cognate may not be a "simplifying" pattern for French-speaking children, even for children with CAS.

\section{Comparison with other non-English studies}

There are very few studies exploring CAS features in other languages than English. This lack of diversity in studies impacts our understanding of the core deficits of CAS. For example, in English-speaking children, a possible core deficit may be prosodic (Murray et al., 2015), yet the absence of lexical stress and regularity of syllabic stress in French makes this feature unlikely in French-speaking children. In other languages, it seems that inconsistency is considered as a core feature of CAS (Malmenholt, Lohmander \& McAllister, 2017 in Swedish; Wong, Lee \& Tong, 2020, in Cantonese). But these studies rely on SLPs' report of what diagnostic features they use for CAS in their clinical practice. It appears that inconsistency may be often used as a diagnostic feature, but no experimental results are available. There is a need for international collaboration as indicated by Wong et al. (2020) to improve our understanding of CAS and SSD. We need to identify which features are English-specific and which are core features of SSD subtypes.

\section{Limitations and future directions}

The main limitation is the challenge in identifying subtypes of SSD, including CAS, in a language where clinical markers have not been fully described. We first assigned children to three groups based on clinical impression. Then, we compared this categorization to quantitative measures of their speech. There is 
Preliminary version produced by the authors.

Geneviève Meloni, Valérie Schott-Brua, Anne Vilain, Hélène Lœvenbruck, Eulalies Consortium*, et al.. Application of childhood apraxia of speech clinical markers to French-speaking children: A preliminary study. International Journal of Speech-Language Pathology, 2020, 22 (6), pp.683-695. 〈10.1080/17549507.2020.1844799〉. 〈hal-03344800〉

*Consortium EULALIES (alphabetical order): Gillet-Perret, E. (CRTLA, CHUGA), Machart, L. (LPNC-GIPSA-lab), Puissant C. (GIPSA-lab)

circularity in this approach, given that it aims at identifying which features may differentiate between groups, but some of these features may have underlaid guidelines when defining the groups. Such an approach tends to reinforce traditional definition of CAS (Rvachew \& Brosseau-Lapré, 2018). However, the aim of the study was not to assess whether the markers accurately distinguish CAS from PD, but rather whether English markers can capture the impressionistic descriptions provided by the French SLPs. In fact, two operationalized quantitative measures do corroborate SLPs' differential diagnosis of CAS: DDK rate and vowel errors in non-word repetition task. In order to fully avoid the circularity challenge, we plan to conduct cluster analyses in the next stage of the EULALIES project, with a larger clinical sample. The second limitation of this study is that our quantitative measures do not cover all the speech behaviours described in CAS literature, especially prosodic features. There is a major lack of prosodic description of French-speaking children with and without SSD, which prevented us from making testable hypotheses, but this is an important avenue for future research.

\section{Conclusion}

Our study investigated whether the clinical markers for CAS available in English distinguish between Frenchspeaking children with CAS, with phonological disorder, and with typical development. We recruited 75 typically-developing children, five children diagnosed with CAS, and nine children diagnosed with phonological disorder. All participants were school-aged children from 5;10 to 9;2 years old. The assessment protocol included three speech production tasks: a picture-naming task, a non-word repetition task, and a diadochokinetic task which targeted lexicon retrieval, phonological encoding, motor planning, and motor programming. From these three tasks, we extracted 20 quantitative measures corresponding to commonly accepted clinical features of CAS in English. Our study brings to light three main results: (1) two markers, diadochokinetic rate and vowel errors in non-word repetition, differentiated children with CAS; (2) some markers tended to indicate a severity gradient for distinguishing children with typical development from children with PD and children with CAS; and (3) several features and measures seemed not to be relevant for 
Preliminary version produced by the authors.

Geneviève Meloni, Valérie Schott-Brua, Anne Vilain, Hélène Lœvenbruck, Eulalies Consortium*, et al.. Application of childhood apraxia of speech clinical markers to French-speaking children: A preliminary study. International Journal of Speech-Language Pathology, 2020, 22 (6), pp.683-695. 〈10.1080/17549507.2020.1844799). 〈hal-03344800〉

*Consortium EULALIES (alphabetical order): Gillet-Perret, E. (CRTLA, CHUGA), Machart, L. (LPNC-GIPSA-lab), Puissant C. (GIPSA-lab)

French-speaking children. This study highlights the need for more cross-linguistic research to better understand the core deficits of CAS, and of subtypes of SSD more broadly.

\section{Acknowledgments}

We thank all children participants and their parents, as well as teachers and speech therapists who helped recruit the participants.

\section{Declaration of interest}

The authors report no conflicts of interest. 
Preliminary version produced by the authors.

Geneviève Meloni, Valérie Schott-Brua, Anne Vilain, Hélène Lœvenbruck, Eulalies Consortium*, et al.. Application of childhood apraxia of speech clinical markers to French-speaking children: A preliminary study. International Journal of Speech-Language Pathology, 2020, 22 (6), pp.683-695. 〈10.1080/17549507.2020.1844799〉. 〈hal-03344800〉

*Consortium EULALIES (alphabetical order): Gillet-Perret, E. (CRTLA, CHUGA), Machart, L. (LPNC-GIPSA-lab), Puissant C. (GIPSA-lab)

References

Aircart-de Falco, S. \& Vion, M. (1987). La mise en place du système phonologique du français chez des enfants entre trois et six ans : une étude de la production (Development of phonological system in French-speaking children between three and six years old: a study of production). Cahiers de Psychologie Cognitive - Current Psychology of Cognition, 7, 247-266. https://hal.archives-ouvertes.fr/hal-00133459

American Speech-Language-Hearing Association (ASHA) (2007). Childhood apraxia of speech (Position statement). Retrieved from www.asha.org/policy

Baker, E. \& McLeod, S. (2011). Evidence-Based Practice for children with speech sound disorders: Part 1 Narrative Review, Language, Speech, and Hearing Services in Schools, 42, 102-139. DOI:10.1044/01611461(2010/09-0075)

Bernthal, J. E., Bankson, N. W. \& Flipsen, P. Jr. (2009). Articulation and Phonological Disorders Speech Sound Disorders in Children, Pearson

Bérubé, D., Bernhardt, B. M., Stemberger, J. P. \& Bertrand, A. (2015). Analyse phonologique en français manitobain : étude de cas selon la phonologie non-linéaire (Phonological analysis in Manitoba French: a case study using non-linear phonology). Rééducation Orthophonique, 263, 105-147.

Boersma, Paul \& Weenink, David (2020). Praat: doing phonetics by computer [Computer program]. Version 6.1.16, retrieved 6 June 2020 from http://www.praat.org/ 
Preliminary version produced by the authors.

Geneviève Meloni, Valérie Schott-Brua, Anne Vilain, Hélène Lœvenbruck, Eulalies Consortium*, et al.. Application of childhood apraxia of speech clinical markers to French-speaking children: A preliminary study. International Journal of Speech-Language Pathology, 2020, 22 (6), pp.683-695. 〈10.1080/17549507.2020.1844799〉. 〈hal-03344800〉

*Consortium EULALIES (alphabetical order): Gillet-Perret, E. (CRTLA, CHUGA), Machart, L. (LPNC-GIPSA-lab), Puissant C. (GIPSA-lab)

Broomfield, J. \& Dodd, B. (2004). The nature of referred subtypes of primary speech disability, Child Language

Teaching and Therapy, 20(2), 135-151. DOl:https://doi.org/10.1191/0265659004ct267oa

Brosseau-Lapré, F. \& Rvachew, S. (2018). Developmental Phonological Disorders, Foundations of Clinical

Practice (Second Edition). Plural Publishing Inc.

Brosseau-Lapré, F., Rvachew, S., Macleod, A. A., Findlay, K., Bérubé, D. \& Bernhardt, B. M. (2018). Une vue d'ensemble : les données probantes sur le développement phonologique des enfants francophones canadiens (An Overview of Data on the Phonological Development of French-Speaking Canadian Children). Canadian Journal of Speech-Language Pathology \& Audiology | Revue Canadienne D'orthophonie Et D'audiologie, 42(1), 1-19.

Charron, L. (2015). Réflexions sur les défis dans le diagnostic et la rééducation de la dyspraxie verbale (Thoughts on Challenges in Diagnosis and Rehabilitation of Childhood Apraxia of Speech). Rééducation orthophonique, 263, 187-205.

Felsenfeld, S., Broen, P. A. et McGue, M. (1994). A 28-year follow-up of adults with a history of moderate phonological disorder: Educational and occupational results. Journal of Speech and Hearing Research, 37(6),1341-1353. DOI:10.1044/jshr.3706.1341

Forrest, K. (2003). Diagnostic criteria of developmental apraxia of speech used by clinical speech-language

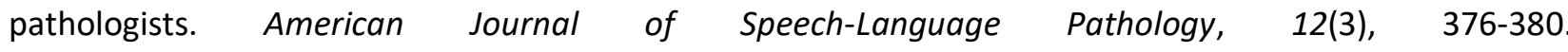
https://doi.org/10.1044/1058-0360(2003/083) 
Preliminary version produced by the authors.

Geneviève Meloni, Valérie Schott-Brua, Anne Vilain, Hélène Lœvenbruck, Eulalies Consortium*, et al.. Application of childhood apraxia of speech clinical markers to French-speaking children: A preliminary study. International Journal of Speech-Language Pathology, 2020, 22 (6), pp.683-695. 〈10.1080/17549507.2020.1844799〉. 〈hal-03344800〉

*Consortium EULALIES (alphabetical order): Gillet-Perret, E. (CRTLA, CHUGA), Machart, L. (LPNC-GIPSA-lab), Puissant C. (GIPSA-lab)

Hedlund, Gregory \& Yvan Rose. 2019. Phon 3.0 \[Computer Software]]. Retrieved from https://phon.ca.

Jacquier-Roux, M., Valdois, S., Zorman, M., Lequette, C., \& Pouget, G. (2005). ODEDYS: un outil de dépistage des dyslexies version 2 (a Dyslexia Screening Tool version 2). Grenoble: Laboratoire cogni-sciences, IUFM de Grenoble.

Kern, S., Langue, J., Zesiger, P. \& Bovet, F. (2010). Adaptations françaises des versions courtes des inventaires du développement communicatif de MacArthur-Bates (French Adaptations of the Short Versions of The MacArthur-Bates Communicative Development). A.N.A.E., 107-108, 217-228

Khomsi, A. (2001). ELO: évaluation du langage oral (ELO: Assessment of spoken language). ECPA, Les Éditions du Centre de psychologie appliquée.

International Expert Panel on Multilingual Children's Speech. (2012). Multilingual children with speech sound disorders: Position paper. Bathurst, Australia: Research Institute for Professional Practice, Learning and Education (RIPPLE), Charles Sturt University. Retrieved from http://www.csu.edu.au/research/multilingual-speech/position-paper

Icht, M., \& Ben-David, B. M. (2014). Oral-diadochokinesis rates across languages: English and Hebrew norms. Journal of Communication Disorders, 48, 27-37. http://dx.doi.org/10.1016/i.jcomdis.2014.02.002

luzzini-Seigel, J., Hogan, T. P., \& Green, J. R. (2017). Speech inconsistency in children with childhood apraxia of speech, language impairment, and speech delay: Depends on the stimuli. Journal of Speech, Language, and Hearing Research, 60(5), 1194-1210. https://doi.org/10.1044/2016 JSLHR-S-15-0184 
Preliminary version produced by the authors.

Geneviève Meloni, Valérie Schott-Brua, Anne Vilain, Hélène Lœvenbruck, Eulalies Consortium*, et al.. Application of childhood apraxia of speech clinical markers to French-speaking children: A preliminary study. International Journal of Speech-Language Pathology, 2020, 22 (6), pp.683-695. 〈10.1080/17549507.2020.1844799〉. 〈hal-03344800〉

*Consortium EULALIES (alphabetical order): Gillet-Perret, E. (CRTLA, CHUGA), Machart, L. (LPNC-GIPSA-lab), Puissant C. (GIPSA-lab)

MacLeod, A. A., Sutton, A., Trudeau, N., \& Thordardottir, E. (2011). The acquisition of consonants in Québécois

French: A cross-sectional study of pre-school aged children. International Journal of Speech-Language

Pathology, 13(2), 93-109. https://doi.org/10.3109/17549507.2011.487543

MacLeod, A.A.N. (2016). Phonetic and phonological perspectives on the acquisition of voice onset time by French-speaking children. Clinical Linguistics \& Phonetics, 30(8), 584-598. DOI:10.3109/02699206.2016.1152509

Malmenholt, A., Lohmander, A., \& McAllister, A. (2017). Childhood apraxia of speech: A survey of praxis and typical speech characteristics. Logopedics Phoniatrics Vocology, 42(2), 84-92.

Masson, P. (2017). Étude de la spécificité d'épreuves langagières chez des enfants présentant une dyspraxie verbale versus un trouble phonologique (Study of Specificity of Language Tests in Children with Childhood Apraxia of Speech versus Phonological Disorder) [Master thesis, Université de Liège]. MatheO. http://hdl.handle.net/2268.2/2321

Meloni, G., Lœvenbruck, H., Vilain, A., Gillet-Perret, E., MacLeod, A. (in press). Évaluation de la perception des sons de parole chez les populations pédiatriques : réflexions sur les épreuves existantes (Assessing Speech Perception in Paediatric Populations: Thoughts on Existing Tools), Glossa.

Monetta, L., Desmarais, C., MacLeod, A.A.N., St-Pierre, M. C., Bourgeois-Marcotte, J., \& Perron, M. (2016). Recension des outils franco-québécois pour l'évaluation des troubles du langage et de la parole (Inventory of Quebec French Tools for Assessing Speech and Language Disorders). Canadian Journal of SpeechLanguage Pathology \& Audiology, 40(2), 165-175. 
Preliminary version produced by the authors.

Geneviève Meloni, Valérie Schott-Brua, Anne Vilain, Hélène Lœvenbruck, Eulalies Consortium*, et al.. Application of childhood apraxia of speech clinical markers to French-speaking children: A preliminary study. International Journal of Speech-Language Pathology, 2020, 22 (6), pp.683-695. 〈10.1080/17549507.2020.1844799〉. 〈hal-03344800〉

*Consortium EULALIES (alphabetical order): Gillet-Perret, E. (CRTLA, CHUGA), Machart, L. (LPNC-GIPSA-lab), Puissant C. (GIPSA-lab)

Murray, E., McCabe, P., Heard, R. \& Ballard, K. J. (2015). Differential Diagnosis of Children with Suspected Childhood Apraxia of Speech, Journal of Speech, Language and Hearing Research, 58, 43-50. DOI:10.1044/2014_JSLHR-S-12-0358

Ozanne, A. (2005). Childhood apraxia of speech. In B. Dodd (Ed.), Differential diagnosis and treatment of children with speech disorders (2nd ed., pp. 71-82). London: Whurr

Paul, M. et Rvachew, S. (2008). Test francophone de phonologie (French Phonology Assessment). http://www.

medicine.mcgill.ca/srvachew/clinical_software_tools_files/TFP_for_website.pdf

Paradis, J., Emmerzael, K., \& Duncan, T. S. (2010). Assessment of English language learners: Using parent report on first language development. Journal of Communication Disorders, 43(6), 474-497. https://doi.org/10.1016/j.jcomdis.2010.01.002

R Development Core Team (2005). R: A language and environment for statistical computing. R Foundation for Statistical Computing, Vienna, Austria. ISBN 3-900051-07-0, URL: http://www.R-project.org.

Rvachew, S. \& Brosseau-Lapré, F. (2015). A randomized trial of 12-week interventions for the treatment of developmental phonological disorder in Francophone children. American Journal of Speech-Language Pathology, 24(4), 637-658. https://doi.org/10.1044/2015 AJSLP-14-0056

Rvachew, S., Marquis, A., Brosseau-Lapré, F., Paul, M., Royle, P. \& Gonnerman, L. (2013). Speech articulation performance of francophone children in the early school years: Norming of the Test de dépistage 
Preliminary version produced by the authors.

Geneviève Meloni, Valérie Schott-Brua, Anne Vilain, Hélène Lœvenbruck, Eulalies Consortium*, et al.. Application of childhood apraxia of speech clinical markers to French-speaking children: A preliminary study. International Journal of Speech-Language Pathology, 2020, 22 (6), pp.683-695. 〈10.1080/17549507.2020.1844799〉. 〈hal-03344800〉

*Consortium EULALIES (alphabetical order): Gillet-Perret, E. (CRTLA, CHUGA), Machart, L. (LPNC-GIPSA-lab), Puissant C. (GIPSA-lab)

francophone de phonologie. Clinical Linguistics \& Phonetics, 27, 950-968.

DOI:10.3109/02699206.2013.830149

Rose, Y. \& Wauquier-Gravelines, S. (2007). French speech acquisition. In S. McLeod (Ed.), The international guide to speech acquisition (364-384). Thomson Delmar Learning.

Savinainen-Makkonen, T. (2000). Word-initial consonant omissions-a developmental process in children learning Finnish. First Language, 20(59), 161-185. https://doi.org/10.1177/014272370002005903

Shriberg, L. D., Lohmeier, H. L., Strand, E. A., \& Jakielski, K. J. (2012). Encoding, memory, and transcoding deficits in childhood apraxia of speech. Clinical Linguistics \& Phonetics, 26(5), 445-482. https://doi.org/10.3109/02699206.2012.655841

Shriberg, L. D., Fourakis, M., Hall, S., Karlsson, H., Lohmeier, H., McSweeny, J., Potter, N., Scheer-Cohen, A., Strand, E., Tilkens, C. \& Wilson, D. (2010). Extensions to the Speech Disorders Classification System (SDCS), Clinical Linguistics \& Phonetics, 24(10), 795-824. DOI:10.3109/02699206.2010.503006.

Shriberg, L. D., Strand, E. A., Fourakis, M., Jakielski, K. J., Hall, S. D., Karlsson, H. B., ... \& Wilson, D. L. (2017). A diagnostic marker to discriminate childhood apraxia of speech from speech delay: I. Development and description of the pause marker. Journal of Speech, Language, and Hearing Research, 60(4), S1096-S1117. https://doi.org/10.1044/2016 JSLHR-S-15-0296 
Preliminary version produced by the authors.

Geneviève Meloni, Valérie Schott-Brua, Anne Vilain, Hélène Lœvenbruck, Eulalies Consortium*, et al.. Application of childhood apraxia of speech clinical markers to French-speaking children: A preliminary study. International Journal of Speech-Language Pathology, 2020, 22 (6), pp.683-695. 〈10.1080/17549507.2020.1844799〉. 〈hal-03344800〉

*Consortium EULALIES (alphabetical order): Gillet-Perret, E. (CRTLA, CHUGA), Machart, L. (LPNC-GIPSA-lab), Puissant C. (GIPSA-lab)

Terband, H., Maassen, B., \& Maas, E. (2019). A psycholinguistic framework for diagnosis and treatment planning of developmental speech disorders. Folia Phoniatrica et Logopaedica, 71(5-6), 216-227. https://doi.org/10.1159/000499426

Van der Merwe, A. (2009). A theoretical framework for the characterization of pathological speech sensorimotor control. In: McNeil, M. R. ed. Clinical Management of Sensorimotor Speech Disorders. New York/Stuttgart: Thiem.

Vinter, S. (2001). Les habiletés phonologiques chez l'enfant de deux ans (Phonological Skills in Two-Year-Old Children). Glossa, 77, 4-19.

Waring, R. \& Knight, R. (2013). How should children with speech sound disorders be classified? A review and critical evaluation of current classification systems, International Journal of Language \& Communication Disorders, 48(1), 25-40. DOI:10.1111/j.1460-6984.2012.00195.x

Wong, E. C., Lee, K. Y., \& Tong, M. C. (2020). The Applicability of the Clinical Features of English Childhood Apraxia of Speech to Cantonese: A Modified Delphi Survey. American Journal of Speech-Language Pathology, 29(2), 652-663. https://doi.org/10.1044/2019 AJSLP-19-00118 
Table I:

Primary characteristics of Childhood Apraxia of Speech and Phonological Disorder

\begin{tabular}{|c|c|c|}
\hline Cover terms & Childhood Apraxia of Speech & Phonological Disorder \\
\hline $\begin{array}{l}\text { Level of } \\
\text { breakdown }\end{array}$ & $\begin{array}{l}\text { Impaired ability to convert } \\
\text { phonological codes to motor speech } \\
\text { commands (speech motor planning } \\
\text { and programming) }\end{array}$ & $\begin{array}{l}\text { Primary difficulties at representational } \\
\text { level including auditory-perceptual } \\
\text { encoding and/or phonological memory } \\
\text { and/or in phonological encoding. }\end{array}$ \\
\hline Prevalence $^{1}$ & $\begin{array}{l}\text { A very small minority of children with } \\
\text { Speech Sound Disorders ( } 5 \% \text { or less) }\end{array}$ & $\begin{array}{c}\text { Around } 20 \% \text { of children with Speech } \\
\text { Sound Disorders }\end{array}$ \\
\hline $\begin{array}{l}\text { Speech } \\
\text { errors types }\end{array}$ & $\begin{array}{c}\text { Inconsistency in speech errors } \mathrm{s}^{\mathrm{a}, \mathrm{c}, \mathrm{d}} \\
\text { Vowel and consonant distortions }^{\mathrm{e}} \\
\text { Syllable segregation } \\
\text { Inappropriate prosody }^{\mathrm{a}, \mathrm{e}} \\
\text { Inappropriate pauses }^{\mathrm{f}} \\
\text { Voicing errors }^{\mathrm{d}, \mathrm{e}} \\
\text { Slow diadochokinetic rate } \\
\text { Schwa epentheses } \\
\text { (ncheased difficulty with longer } \\
\text { words }^{\mathrm{e}}\end{array}$ & $\begin{array}{l}\text { Speech errors that are frequently } \\
\text { observed in younger typically } \\
\text { developing peers }{ }^{\mathrm{i}} \text {. } \\
\text { High occurrence of omissions, } \\
\text { substitutions, distortions, or cluster } \\
\text { simplifications that eliminate } \\
\text { meaningful contrasts between words. } \\
\text { Children's representation of speech } \\
\text { sounds may lack precision and } \\
\text { robustness } \\
\text { j }\end{array}$ \\
\hline
\end{tabular}

Note. ${ }^{1 \cdot}$ Estimate proportion of Childhood Apraxia of Speech and Phonological Disorder is highly variable (Law et al., 2000).

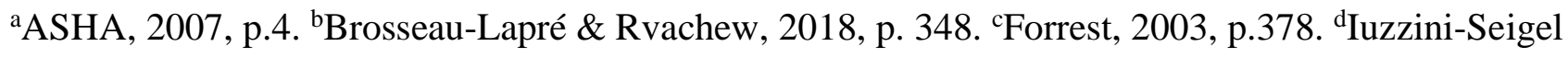

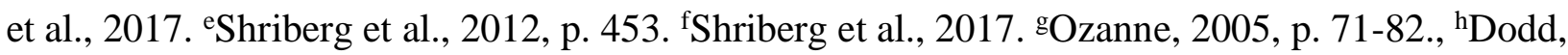

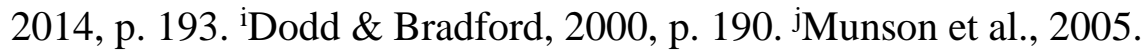


Preliminary version produced by the authors.

Geneviève Meloni, Valérie Schott-Brua, Anne Vilain, Hélène Lœvenbruck, Eulalies Consortium*, et al.. Application of childhood apraxia of speech clinical markers to French-speaking children: A preliminary study. International Journal of Speech-Language Pathology, 2020, 22 (6), pp.683-695. 〈10.1080/17549507.2020.1844799〉. 〈hal-03344800〉

Figure 1. (A) Errors on consonants. (B) Errors on vowels.
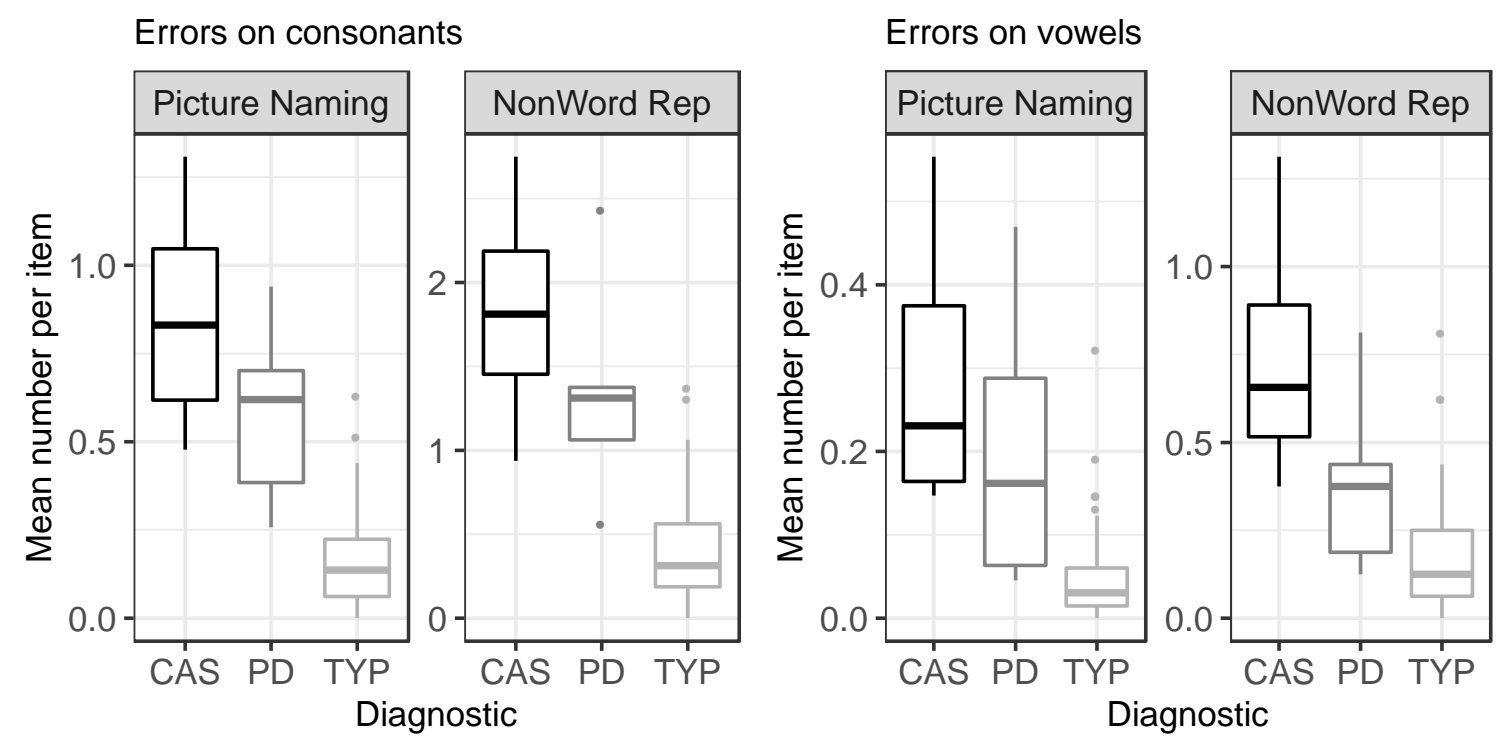

Figure 2. (A) Consonant epentheses. (B) Errors on consonant clusters.
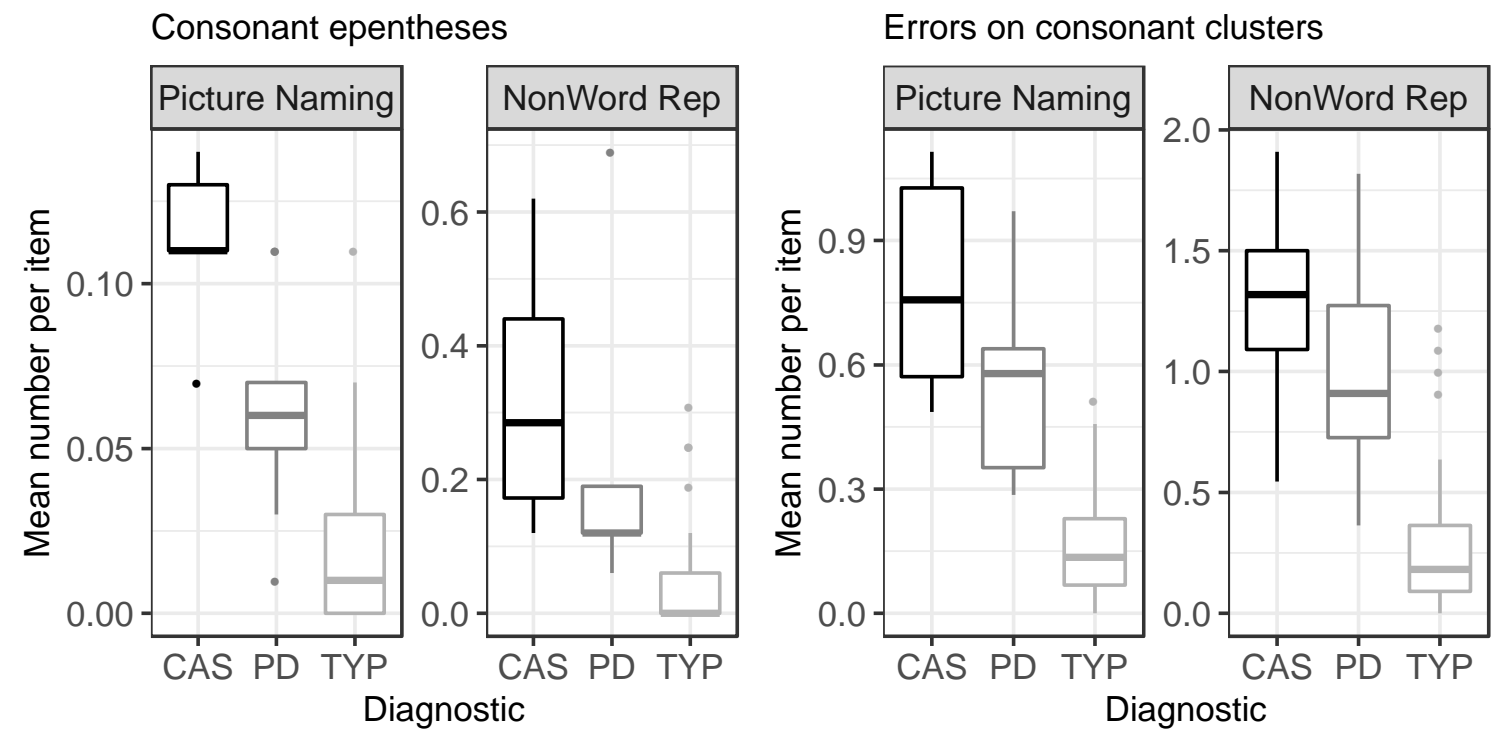
Figure 3. (A) Prevoicing errors. (B) Devoicing errors.
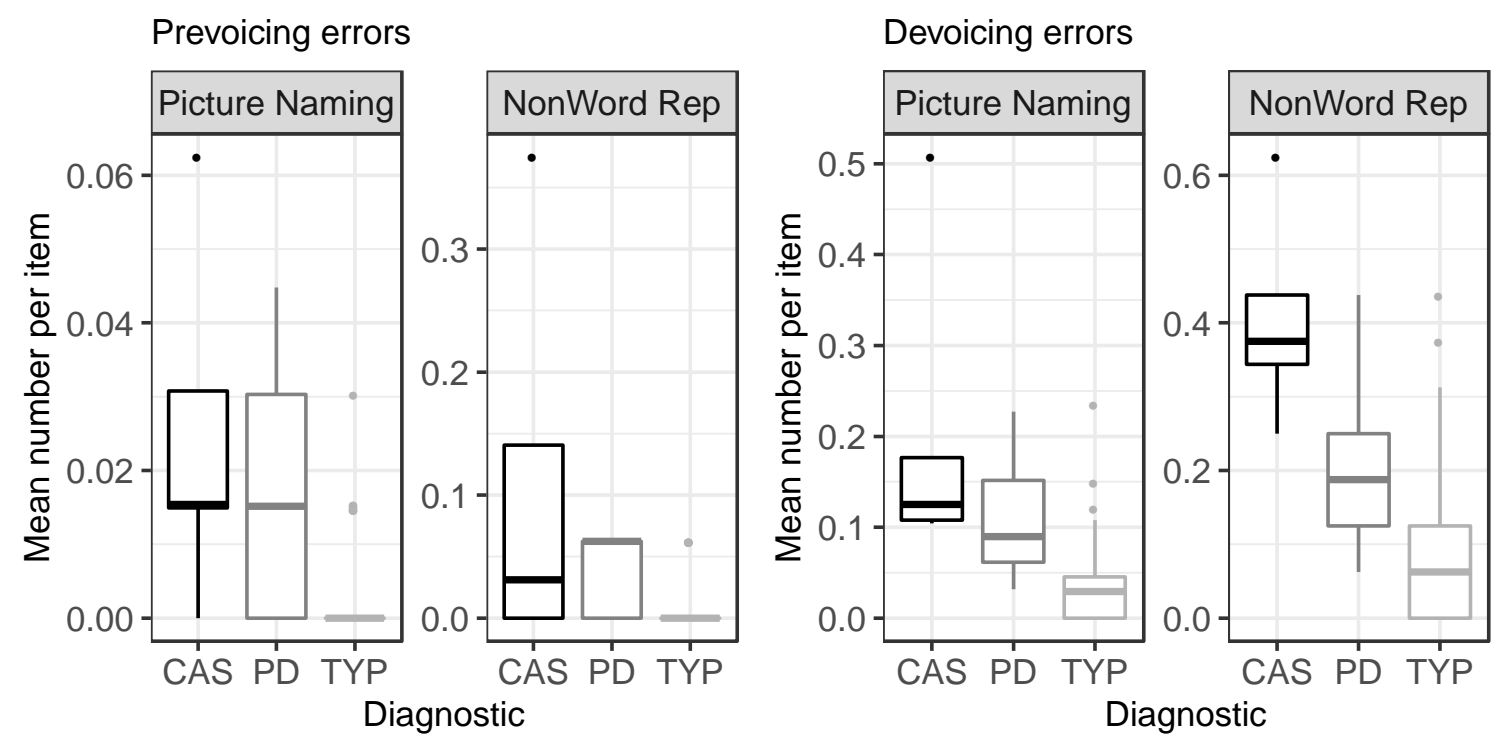

Figure 4. (A) Diadochokinesis rate. (B) Inconsistency score.
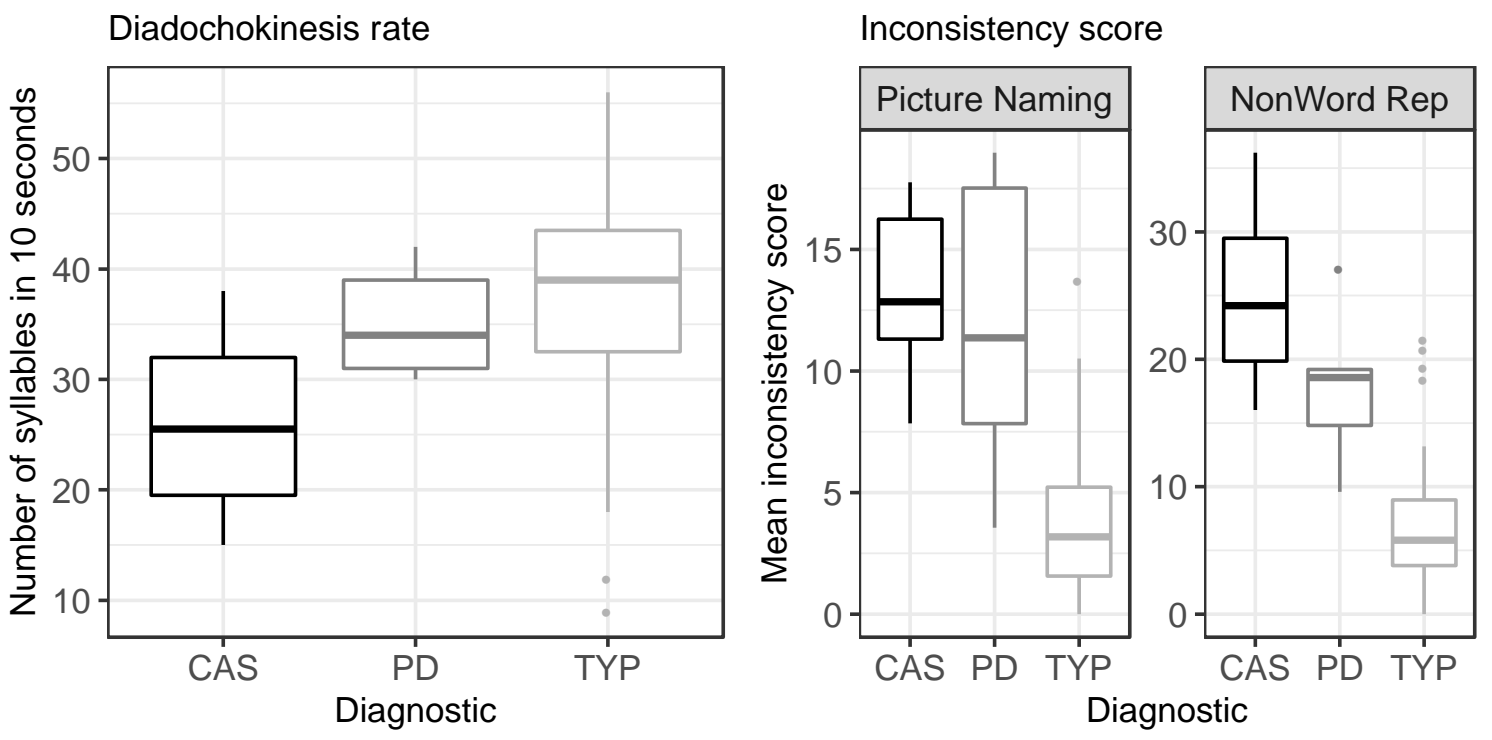
Appendix A

Differences in the phonological systems of France French and American English.

\begin{tabular}{|c|c|c|}
\hline & France French & American English \\
\hline $\begin{array}{l}\text { Consonant } \\
\text { inventory }\end{array}$ & $\begin{array}{l}/ p t k b d g f s \int v z z \mid \text { в } m \text { n n (n)ju } \\
w /\end{array}$ & $\begin{array}{l}/ p t k b d g f \theta s \int h v \delta z 3 t \int d 3 I d \\
m n \eta j w /\end{array}$ \\
\hline Vowel inventory & 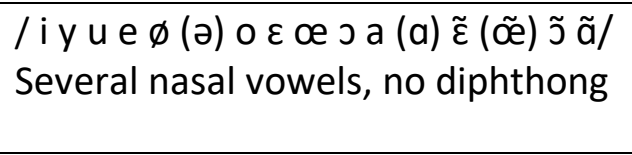 & 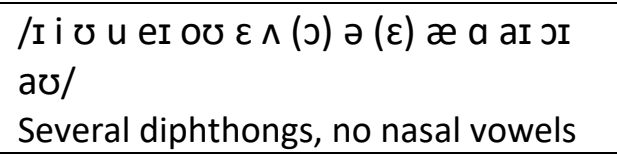 \\
\hline $\begin{array}{l}\text { Phonetic } \\
\text { realizations }\end{array}$ & $\begin{array}{l}\text {-Stops are unaspirated } \\
\text {-Voiced stops are pre-voiced } \\
\text {-Variable schwa: schwa alternates } \\
\text { with zero depending on lexical, } \\
\text { syntactic, prosodic and sociolinguistic } \\
\text { factors }\end{array}$ & $\begin{array}{l}\text {-Voiceless stops are aspirated in some } \\
\text { positions and can be glottalized in } \\
\text { others } \\
\text {-Voiced stops can be realized as } \\
\text { voiced or voiceless unaspirated. } \\
\text {-unstressed vowels tend to be } \\
\text { reduced durationally and qualitatively }\end{array}$ \\
\hline $\begin{array}{l}\text { Most frequent } \\
\text { syllable types }\end{array}$ & $\begin{array}{l}\mathrm{CV}, \mathrm{CVC}, \mathrm{CCV}, \mathrm{V}, \mathrm{VC}, \mathrm{CCGV}, \mathrm{CVCCC} \\
\text { Onsets and codas can be complex: } \\
\mathrm{C}_{(0-3) \mathrm{VC}(0-4)}\end{array}$ & $\begin{array}{l}\text { Onsets and codas can be complex: } \\
\mathrm{C}_{(0-3)} \mathrm{VC}(0-5) \\
\text { - Liquids and nasals can be syllabic }\end{array}$ \\
\hline $\begin{array}{l}\text { Phonotactic } \\
\text { rules }\end{array}$ & $\begin{array}{l}\text {-Only certain consonants are } \\
\text { permitted in complex onsets and } \\
\text { codas: /s/+obstruent+liquid or glide } \\
\text { (or both in onsets in medial word } \\
\text { positions). } \\
\text {-Liaison and enchainment processes } \\
\text { increase the frequency of word-initial } \\
\text { /z/ and /n/ } \\
\text {-Loi de position favours the } \\
\text { appearance of mid-low vowels in } \\
\text { closed syllables and mid-high vowels } \\
\text { in open syllables } \\
\text {-onset and coda clusters generally } \\
\text { obey sonority sequencing: the most } \\
\text { sonorant segments are nearest the } \\
\text { nucleus (except for CCC onsets with } \\
\text { initial /s/) }\end{array}$ & $\begin{array}{l}\text { - Stop-nasal sequences are ruled out } \\
\text { - Only /s/ and // /are permitted before } \\
\text { a stop, either oral or nasal, in word- } \\
\text { initial position } \\
\text { - Onsets may not consist of two } \\
\text { consonants with the same place of } \\
\text { articulation } \\
\text {-Onset and coda clusters generally } \\
\text { obey sonority sequencing } \\
\text { - The vowel of a stressed open word- } \\
\text { final syllable may not be short }\end{array}$ \\
\hline Word length & $\begin{array}{l}\text {-The early French lexicon has more } \\
\text { multisyllabic words (66\%) than } \\
\text { monosyllabic words (33\%). } \\
\text {-Four syllable words are frequent in } \\
\text { the adult lexicon. }\end{array}$ & $\begin{array}{l}\text { The early English lexicon has more } \\
\text { monosyllabic }(61 \%) \text { than multisyllabic } \\
(38 \%) \text { words. }\end{array}$ \\
\hline Prosody & $\begin{array}{l}\text { Syllable-timed, no lexical stress, most } \\
\text { frequent metric pattern: iambic }\end{array}$ & $\begin{array}{l}\text { Stress-timed, most frequent metric } \\
\text { pattern: trochaic }\end{array}$ \\
\hline
\end{tabular}


Preliminary version produced by the authors.

Geneviève Meloni, Valérie Schott-Brua, Anne Vilain, Hélène Lœvenbruck, Eulalies Consortium*, et al.. Application of childhood apraxia of speech clinical markers to French-speaking children: A preliminary study. International Journal of Speech-Language Pathology, 2020, 22 (6), pp.683-695. 〈10.1080/17549507.2020.1844799〉. 〈hal-03344800〉

\section{Supplemental Material}

\section{Supplementary Material A:}

Description of the participants

\begin{tabular}{|c|c|c|c|c|}
\hline & & TD group & CAS group & PD group \\
\hline \multicolumn{2}{|c|}{ Number of participants } & 75 & 5 & 9 \\
\hline \multicolumn{2}{|r|}{ Mean age (SD) } & $85.83(8.82)$ & $88.8(12.43)$ & $89.67(10.37)$ \\
\hline \multicolumn{2}{|r|}{ Females/Males } & $41 / 34$ & $2 / 3$ & $2 / 7$ \\
\hline \multicolumn{2}{|r|}{ Monolinguals } & 45 & 5 & 8 \\
\hline \multicolumn{2}{|c|}{ Multilinguals (with two languages daily) } & 25 & 0 & 1 \\
\hline \multicolumn{2}{|c|}{$\begin{array}{c}\text { Multilingual (with three or more } \\
\text { languages daily) }\end{array}$} & 5 & 0 & 0 \\
\hline \multirow{4}{*}{$\begin{array}{l}\text { Contact with } \\
\text { French (for } \\
\text { multilingual } \\
\text { participants) }\end{array}$} & Since birth & 19 & 0 & 1 \\
\hline & $\begin{array}{c}\text { Daycare (between } 2 \\
\text { months to } 3 \text { years } \\
\text { old) }\end{array}$ & 2 & 0 & 0 \\
\hline & $\begin{array}{c}\text { Kindergarten } \\
\text { (between } 3 \text { to } 6 \\
\text { years old) }\end{array}$ & 6 & 0 & 0 \\
\hline & Elementary school & 3 & 0 & 0 \\
\hline \multirow{9}{*}{$\begin{array}{c}\text { Socio- } \\
\text { economic } \\
\text { status } \\
\text { (INSEE, } \\
2014)\end{array}$} & Farmer & 0 & 0 & 0 \\
\hline & $\begin{array}{l}\text { Craftsperson, shopkeeper } \\
\text { or head of a company }\end{array}$ & 6 & 0 & 0 \\
\hline & Executive or manager & 16 & 1 & 0 \\
\hline & Intermediate occupation & 6 & 0 & 1 \\
\hline & Employee & 12 & 0 & 0 \\
\hline & Worker & 0 & 0 & 1 \\
\hline & Retired & 0 & 0 & 0 \\
\hline & Unemployed & 7 & 1 & 1 \\
\hline & No information & 28 & 3 & 6 \\
\hline
\end{tabular}




\section{Supplementary Material B:}

Description of the nonwords repetition task (NWR)

\begin{tabular}{|c|c|c|c|c|}
\hline Nonwords & $\begin{array}{l}\text { Phonotactic } \\
\text { frequency }^{\mathrm{a}}\end{array}$ & $\begin{array}{l}\text { Syllable structure } \\
\text { (C: consonant, V: } \\
\text { vowel, G: glide) }\end{array}$ & Syllable length & $\begin{array}{c}\text { Lexical } \\
\text { component }^{\mathbf{b}}\end{array}$ \\
\hline 3õtjø & 0.003 & CV.CGV & 2 & - \\
\hline gufã & 0.039 & CV.CV & 2 & - \\
\hline tธعsmœl & 0.307 & CCVC.CVC & 2 & - \\
\hline vвalon & 0.096 & CCV.CVC & 2 & - \\
\hline Јозувг̃ & 0.019 & CV.CV.CV & 3 & $\begin{array}{c}\text { chaussure, } \\
\text { / } \text { Јosys/ (shoe) }\end{array}$ \\
\hline dyлеке & 0.355 & CV.CV.CV & 3 & - \\
\hline zebuifã & 0.007 & CV.CGV.CV & 3 & - \\
\hline kanargloz & 0.334 & CV.CVC.CCVC & 3 & $\begin{array}{c}\text { canard, /kanas/ } \\
\text { (duck) }\end{array}$ \\
\hline fœьріidsak & 0.365 & CVC.CV.CCVC & 3 & - \\
\hline 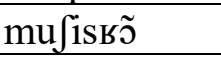 & 0.091 & CV.CVC.CV & 3 & - \\
\hline vwatyвotã & 0.277 & CGV.CV.CV.CV & 4 & $\begin{array}{c}\text { voiture, / } \\
\text { vwatys/ (car) }\end{array}$ \\
\hline pukosẽta & 0.22 & CV.CV.CV.CV & 4 & - \\
\hline lazynig̃ & 0.151 & CV.CV.CV.CV & 4 & - \\
\hline adbalõziь & 0.246 & CVC.CV.CV.CVC & 4 & $\begin{array}{l}\text { ballon, /bals/ } \\
\text { (ball) }\end{array}$ \\
\hline øbьоlistiқ & 0.643 & V.CCV.CVC.CVC & 4 & - \\
\hline spelyzbavez & 0.101 & CCV.CVC.CV.CVC & 4 & - \\
\hline
\end{tabular}

Note. ${ }^{a}$ Variability in the phonotactic frequency of nonwords was introduced to modulate complexity.

Phonotactic frequency was computed from occurrence counts in the database LEXIQUE 2.62 (2005).

It is calculated as the average of the frequencies of interest, which are:

- frequency of the onset-nucleus sequence in syllables 1 and 2 and, if applicable syllables 3 and 4 ,

- frequency of the coda consonant in each syllable, if applicable,

- frequency of the heterosyllabic cluster if applicable. 
To calculate each frequency, a ratio is calculated between the number of occurrences of each sequence and the total number of first, second, (third and fourth if applicable) syllables in the database.

${ }^{b}$ These words intend to be easily accessible for children and have been selected from the words of the French MacArthur Bates Communicative Development Index (Kern, Zesiger \& Bovet, 2009)

Segmental distribution for the nonword repetition task

\begin{tabular}{|c|c|c|c|c|c|}
\hline & 1st syllable & 2nd syllable & 3rd syllable & 4th syllable & Total \\
\hline $\mathrm{p}$ & $\begin{array}{c}\text { pukosẽta } \\
\text { spelyzbavez }\end{array}$ & fœьріdьак & & & 3 \\
\hline $\mathrm{t}$ & tвєsmœl & $\begin{array}{c}\text { 3テ̃tjø } \\
\text { vwatyкotã }\end{array}$ & & 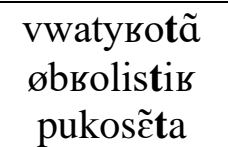 & 5 \\
\hline $\mathrm{k}$ & kanasgloz & pukosẽta & fœьрідкаk & & 3 \\
\hline $\mathrm{b}$ & & $\begin{array}{c}\text { zebuifã } \\
\text { adbalõziь } \\
\text { фbьolistiь }\end{array}$ & spelyzbavez & & 4 \\
\hline $\mathrm{d}$ & $\begin{array}{c}\text { dynese } \\
\text { adbalõzis }\end{array}$ & & fœьріdьак & & 3 \\
\hline $\mathrm{g}$ & gufã & & kanasgloz & lazynig̃ & 3 \\
\hline $\mathrm{f}$ & fœьріdкаk & & zebuifã & & 2 \\
\hline $\mathrm{s}$ & 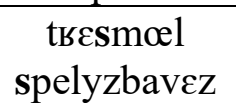 & 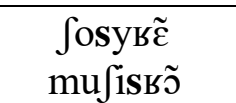 & pukos ̃̃ta & øььоlistiь & 5 \\
\hline $\int$ & 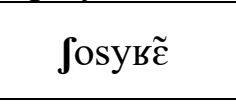 & $\begin{array}{c}\text { gufã } \\
\text { mufissõ }\end{array}$ & & & 3 \\
\hline $\mathrm{V}$ & $\begin{array}{c}\text { vваləj } \\
\text { vwatysotã }\end{array}$ & & & spelyzbavez & 3 \\
\hline $\mathrm{Z}$ & zebuifã & spelyzbavez & kanasgloz & $\begin{array}{c}\text { adbalõziь } \\
\text { spelyzbavez }\end{array}$ & 5 \\
\hline 3 & 3ว̃tjø & lazynig̃ & & & 2 \\
\hline В & 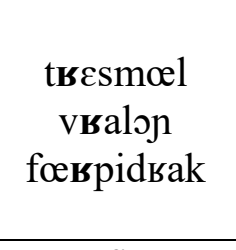 & $\begin{array}{l}\text { kanasgloz } \\
\text { фbrolistí }\end{array}$ & 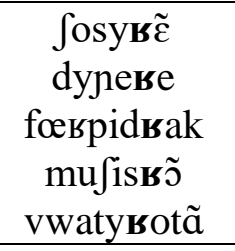 & $\begin{array}{l}\text { adbalõzí } \\
\text { øbьolistiı }\end{array}$ & 13 \\
\hline $\mathrm{m}$ & $\mathbf{m u \int i s к \tilde { ~ }}$ & tьEsmœl & & & 2 \\
\hline $\mathrm{n}$ & & kanasgloz & lazynig̃̃ & & 3 \\
\hline
\end{tabular}




\begin{tabular}{|c|c|c|c|c|c|}
\hline 1 & lazynig̃̃ & $\begin{array}{c}\text { tвєsmœl } \\
\text { vвalon } \\
\text { spelyzbavez } \\
\end{array}$ & $\begin{array}{l}\text { kanargloz } \\
\text { adbalõziь } \\
\text { øbьolistis } \\
\end{array}$ & & 7 \\
\hline $\mathrm{n}$ & & $\begin{array}{l}\text { vваlon } \\
\text { dуреве }\end{array}$ & & & 2 \\
\hline $\mathrm{a}$ & 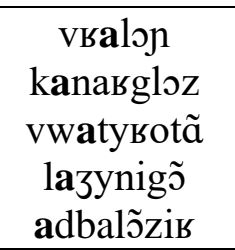 & $\begin{array}{l}\text { kanasgloz } \\
\text { adbalõzis }\end{array}$ & $\begin{array}{c}\text { fœьрідьak } \\
\text { spelyzbavez }\end{array}$ & pukosẽta & 9 \\
\hline $\mathrm{e}$ & $\begin{array}{c}\text { spelyzbavez } \\
\text { zebuifã }\end{array}$ & дуреке & dуреке & & 3 \\
\hline$\varepsilon$ & tsesmœl & & & spelyzbavez & 2 \\
\hline$\varnothing$ & øььоlistí & 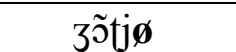 & & & 2 \\
\hline$œ$ & fœьріidкак & tьEsmœel & & & 2 \\
\hline o & 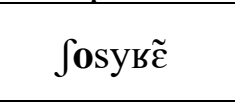 & $\begin{array}{l}\text { pukosẽ̃ta } \\
\text { øbsolistis }\end{array}$ & vwatyвоtã & & 4 \\
\hline 0 & & vваlon & kапавgləz & & 2 \\
\hline $\mathrm{i}$ & & $\begin{array}{c}\text { zebuifã } \\
\text { fœьрidьak } \\
\text { muJisьว̃ } \\
\end{array}$ & lazynigõ & $\begin{array}{l}\text { pukonẽ்i } \\
\text { adbalõziь } \\
\text { øbsolistí }\end{array}$ & 8 \\
\hline $\mathrm{u}$ & 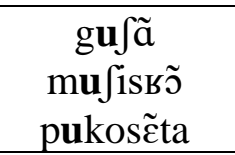 & & & & 3 \\
\hline $\mathrm{y}$ & dулеве & 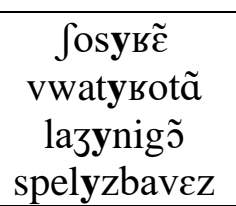 & & & 5 \\
\hline$\tilde{\mathrm{a}}$ & & $\operatorname{gu} \int \tilde{\mathbf{a}}$ & zebuifã & vwatysotã & 3 \\
\hline$\tilde{\tilde{\jmath}}$ & 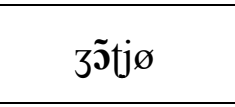 & & 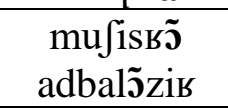 & 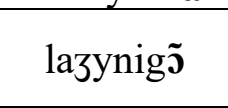 & 4 \\
\hline$\tilde{\varepsilon}$ & & & 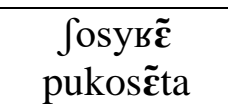 & & 2 \\
\hline $\mathrm{j}$ & & 3ว̃tjø & & & 1 \\
\hline $\mathrm{W}$ & vwatysotã & & & & 1 \\
\hline 4 & & zebuifã & & & 1 \\
\hline
\end{tabular}

Note. Segments appear at least two times in different word positions, except for glides which appear only once. 


\section{Supplementary Material C:}

\begin{tabular}{|c|c|c|c|c|c|}
\hline Items & API & Translation & Items & API & Translation \\
\hline \multicolumn{6}{|c|}{1 syllable } \\
\hline fraise & fьEZ & strawberry & hibou & i.bu & owl \\
\hline gare & gав & $\begin{array}{c}\text { railway } \\
\text { station }\end{array}$ & Indien & $\tilde{\varepsilon} \cdot \operatorname{dj} \tilde{\varepsilon}$ & $\begin{array}{c}\text { Indian } \\
\text { (person from } \\
\text { India) }\end{array}$ \\
\hline griffe & grif & claw & menton & mã.tõ & chin \\
\hline huile & yil & oil & poisson & pwa.s̃̃ & fish \\
\hline jambe & $3 \tilde{a} b$ & leg & tomate & to.mat & tomato \\
\hline langue & lãg & tongue & voiture & vwa.tys & car \\
\hline livre & livs & book & yaourt & ja.ust & yoghurt \\
\hline loup & lu & wolf & aquarium & a.kwa.rjom & aquarium \\
\hline main & $m \tilde{\varepsilon}$ & hand & chocolat & So.ko.la & chocolate \\
\hline neige & $\mathrm{n} \varepsilon 3$ & snow & cinéma & si.ne.ma & cinema \\
\hline œuf & œf & egg & couverture & ku.ver.tys & blanket \\
\hline ongle & õgl & finger nail & crocodile & kbo.ko.dil & crocodile \\
\hline ours & üS & bear & déguisement & de.giz.mã & costume \\
\hline peigne & pen & comb & éléphant & e.le.fã & elephant \\
\hline pieuvre & рјœvь & octopus & escargot & es.kaь.go & snail \\
\hline robe & воb & dress & oreiller & oreje & pillow \\
\hline stade & stad & stadium & parapluie & ра.ьа.plчi & umbrella \\
\hline tigre & tigs & tiger & pyjama & pi.za.ma & pyjamas \\
\hline zèbre & zebs & zebra & téléphone & te.le.fon & telephone \\
\hline \multicolumn{6}{|c|}{2 syllables } \\
\hline avion & avjõ & aeroplane & toboggan & to.bo.gã & $\begin{array}{l}\text { playground } \\
\text { slide }\end{array}$ \\
\hline biberon & bi.bиว̃ & baby's bottle & uniforme & у.ni.fวьт & uniform \\
\hline bonhomme & bo.nom & person & aspirateur & as.pi.ьа.tœь & $\begin{array}{l}\text { vacuum } \\
\text { cleaner }\end{array}$ \\
\hline camion & ka.mjõ & truck & bibliothèque & bi.bli.o.tck & library \\
\hline capuche & ka.py & hood & extraterrestre & $\begin{array}{c}\text { ek.stвa.te.ьєs } \\
\text { tв }\end{array}$ & alien \\
\hline chaussette & 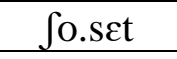 & sock & hélicoptère & e.li.kəp.tєь & helicopter \\
\hline ciseaux & si.zo & scissors & hippopotame & i.po.po.tam & $\begin{array}{c}\text { hippopotamu } \\
\text { s }\end{array}$ \\
\hline citron & si.tьว̃ & lemon & locomotive & lo.ko.mo.tiv & locomotive \\
\hline dentiste & dã.tist & dentist & $\begin{array}{c}\text { machine à } \\
\text { laver }\end{array}$ & ma.fi.na.la.ve & $\begin{array}{l}\text { washing } \\
\text { machine }\end{array}$ \\
\hline docteur & dok.tœь & doctor & médicament & me.di.ka.mã & $\begin{array}{l}\text { medicine } \\
\text { (pill) }\end{array}$ \\
\hline
\end{tabular}


Preliminary version produced by the authors.

Geneviève Meloni, Valérie Schott-Brua, Anne Vilain, Hélène Lœvenbruck, Eulalies Consortium*, et al.. Application of childhood apraxia of speech clinical markers to French-speaking children: A preliminary study. International Journal of Speech-Language Pathology, 2020, 22 (6), pp.683-695. 〈10.1080/17549507.2020.1844799〉. 〈hal-03344800〉

*Consortium EULALIES (alphabetical order): Gillet-Perret, E. (CRTLA, CHUGA), Machart, L. (LPNC-GIPSA-lab), Puissant C. (GIPSA-lab)

\begin{tabular}{|c|c|c|c|c|c|}
\hline euro & ф.ко & euro & ordinateur & ов.di.na.tœк & computer \\
\hline enveloppe & ã.vlop & envelope & rhinocéros & вi.no.se.kos & rhinoceros \\
\hline farine & fa.sin & flour & supermarché & $\begin{array}{c}\text { sу.рвь.тав. } \\
\text { e } \\
\end{array}$ & supermarket \\
\hline fourchette & fuь. $\int \varepsilon t$ & fork & ventilateur & vã.ti.la.tœь & fan \\
\hline grenouille & gьф.nuj & frog & vétérinaire & ve.te.si.nes & veterinarian \\
\hline
\end{tabular}

Description of items' lexical frequency of the picture-naming task (PN)

\begin{tabular}{|c|c|c|c|c|c|c|c|}
\hline \multicolumn{2}{|c|}{1 syllable } & \multicolumn{2}{|c|}{2 syllables } & \multicolumn{2}{|c|}{3 syllables } & \multicolumn{2}{|c|}{4 syllables } \\
\hline Items & $\begin{array}{c}\text { Lexical } \\
\text { frequenc } \\
\mathbf{y}^{\mathbf{a}} \\
\end{array}$ & Items & $\begin{array}{c}\text { Lexical } \\
\text { frequenc } \\
\mathbf{y} \\
\end{array}$ & Items & $\begin{array}{c}\text { Lexical } \\
\text { frequenc } \\
\mathbf{y} \\
\end{array}$ & Items & $\begin{array}{c}\text { Lexical } \\
\text { frequenc } \\
\mathbf{y} \\
\end{array}$ \\
\hline fraise & 60.54 & avion & 63.71 & aquarium & 53.47 & $\begin{array}{c}\text { aspira- } \\
\text { teur }\end{array}$ & 53.26 \\
\hline gare & 61.70 & biberon & 55.87 & chocolat & 66.50 & $\begin{array}{l}\text { biblio- } \\
\text { thèque }\end{array}$ & 56.04 \\
\hline griffe & 36.25 & $\begin{array}{c}\text { bonhom- } \\
\text { me }\end{array}$ & 61.04 & cinéma & 62.01 & $\begin{array}{c}\text { extrater- } \\
\text { restre }^{\mathrm{a}}\end{array}$ & - \\
\hline huile & 57.25 & camion & 62.07 & $\begin{array}{c}\text { couvertur } \\
\mathrm{e}\end{array}$ & 53.85 & $\begin{array}{l}\text { hélicop- } \\
\text { tère }\end{array}$ & 57.34 \\
\hline jambe & 59.13 & capuche & 35.74 & crocodile & 61.74 & $\begin{array}{c}\text { hippopo- } \\
\text { tame }\end{array}$ & 55.97 \\
\hline langue & 60.56 & $\begin{array}{c}\text { chausset- } \\
\text { te }\end{array}$ & 45.86 & $\begin{array}{c}\text { déguise- } \\
\text { ment }\end{array}$ & 42.59 & $\begin{array}{l}\text { locomo- } \\
\text { tive }\end{array}$ & 56.85 \\
\hline livre & 67.85 & ciseaux & 58.79 & éléphant & 64.20 & $\begin{array}{l}\text { machine } \\
\text { à laver }\end{array}$ & 60.72 \\
\hline loup & 67.13 & citron & 61.01 & escargot & 56.74 & $\begin{array}{c}\text { médica- } \\
\text { ment }\end{array}$ & 51.29 \\
\hline main & 66.05 & dentiste & 55.35 & oreiller & 57.88 & $\begin{array}{c}\text { ordina- } \\
\text { teur }\end{array}$ & 51.35 \\
\hline neige & 67.41 & docteur & 55.98 & parapluie & 60.36 & $\begin{array}{l}\text { rhinocé- } \\
\text { ros }\end{array}$ & 51.04 \\
\hline œuf & 65.07 & euro $^{a}$ & - & pyjama & 58.64 & $\begin{array}{l}\text { super- } \\
\text { marché }\end{array}$ & 53.48 \\
\hline ongle & 54.56 & $\begin{array}{l}\text { envelop- } \\
\text { pe }\end{array}$ & 60.70 & téléphone & 63.31 & $\begin{array}{c}\text { ventila- } \\
\text { teur }^{\mathrm{a}}\end{array}$ & - \\
\hline ours & 68.08 & farine & 63.61 & toboggan & 52.65 & $\begin{array}{l}\text { vétéri- } \\
\text { naire }\end{array}$ & 45.98 \\
\hline peigne & 58.88 & $\begin{array}{c}\text { fourchet- } \\
\text { te }\end{array}$ & 55.13 & uniforme & 50.77 & & \\
\hline pieuvre & 31.86 & $\begin{array}{c}\text { grenouil- } \\
\text { le }\end{array}$ & 61.11 & & & & \\
\hline robe & 64.10 & hibou & 59.30 & & & & \\
\hline stade & 46.06 & indien & 56.33 & & & & \\
\hline
\end{tabular}




\begin{tabular}{ll|ll|l|l}
\hline \multicolumn{2}{l|}{} & & & & \\
\hline tigre & 59.27 & menton & 57.19 & & \\
\hline zèbre 60.80 & poisson 68.65 & & \\
\hline & tomate & 56.75 & & \\
\hline & voiture 68.79 & & \\
\hline & yaourt & 57.36 & & \\
\hline
\end{tabular}

Note. Lexical frequencies come from MANULEX database (Lété, Sprenger-Charolles \& Colé,

2004), which provide word-frequency lists of non-lemmatized and lemmatized words computed from

the 1.9 million words taken from 54 French elementary-school readers. Here, is indicated the

Standard Frequency Index, which is described as a simple and convenient way of indicating

frequency counts. A wordform or a lemma with an SFI of 70 is expected to occur once in every 1000 words, one with a SFI of 60 is expected to occur every 10000 words.

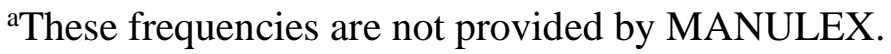

\section{Consonant distribution}

\begin{tabular}{|c|c|c|c|c|c|c|}
\hline & Word-initial & Onset & Coda & Cluster & Word-final & Total \\
\hline $\mathrm{p}$ & $\begin{array}{l}\text { parapluie } \\
\text { pyjama } \\
\text { peigne }\end{array}$ & $\begin{array}{c}\text { supermarché } \\
\text { hippopotame } \\
\text { capuche } \\
\text { aspirateur }\end{array}$ & hélicoptère & $\begin{array}{c}\text { poisson } \\
\text { pieuvre } \\
\text { parapluie }\end{array}$ & enveloppe & 13 \\
\hline $\mathrm{t}$ & $\begin{array}{l}\text { téléphone } \\
\text { toboggan } \\
\text { tomate } \\
\text { tigre }\end{array}$ & $\begin{array}{c}\text { vétérinaire } \\
\text { ventilateur } \\
\text { dentiste } \\
\text { docteur } \\
\text { menton } \\
\text { voiture } \\
\text { extraterrestre } \\
\text { couverture } \\
\text { ordinateur } \\
\text { locomotive } \\
\text { hippopotame } \\
\text { hélicoptère }\end{array}$ & & $\begin{array}{c}\text { stade } \\
\text { extraterrestre } \\
\text { citron } \\
\text { dentiste } \\
\text { yaourt }\end{array}$ & $\begin{array}{l}\text { chaussette } \\
\text { fourchette } \\
\text { tomate }\end{array}$ & 28 \\
\hline
\end{tabular}




\section{bibliothèque \\ aspirateur}

\begin{tabular}{|c|c|c|c|c|c|c|}
\hline $\mathrm{k}$ & $\begin{array}{l}\text { couverture } \\
\text { camion } \\
\text { capuche }\end{array}$ & $\begin{array}{l}\text { locomotive } \\
\text { aquarium } \\
\text { chocolat } \\
\text { crocodile } \\
\text { médicament } \\
\text { hélicoptère }\end{array}$ & docteur & $\begin{array}{c}\text { crocodile } \\
\text { extraterrestre } \\
\text { escargot }\end{array}$ & bibliothèque & 14 \\
\hline $\mathrm{b}$ & $\begin{array}{c}\text { bibliothèque } \\
\text { biberon } \\
\text { bonhomme }\end{array}$ & $\begin{array}{c}\text { toboggan } \\
\text { hibou }\end{array}$ & & $\begin{array}{c}\text { zèbre } \\
\text { bibliothèque } \\
\text { biberon }\end{array}$ & $\begin{array}{c}\text { robe } \\
\text { jambe }\end{array}$ & 10 \\
\hline d & $\begin{array}{l}\text { déguisement } \\
\text { dentiste } \\
\text { docteur }\end{array}$ & $\begin{array}{l}\text { ordinateur } \\
\text { médicament } \\
\text { crocodile }\end{array}$ & & indien & stade & 8 \\
\hline $\mathrm{g}$ & gare & $\begin{array}{l}\text { déguisement } \\
\text { escargot } \\
\text { toboggan }\end{array}$ & & $\begin{array}{c}\text { grenouille } \\
\text { griffe } \\
\text { tigre } \\
\text { ongle } \\
\end{array}$ & langue & 9 \\
\hline $\mathrm{f}$ & $\begin{array}{c}\text { farine } \\
\text { fourchette }\end{array}$ & $\begin{array}{l}\text { éléphant } \\
\text { téléphone } \\
\text { uniforme }\end{array}$ & & fraise & $\begin{array}{l}\text { œuf } \\
\text { griffe }\end{array}$ & 8 \\
\hline $\mathrm{s}$ & $\begin{array}{l}\text { supermarché } \\
\text { cinéma } \\
\text { ciseau } \\
\text { citron }\end{array}$ & $\begin{array}{l}\text { chaussette } \\
\text { poisson }\end{array}$ & $\begin{array}{l}\text { aspirateur } \\
\text { escargot }\end{array}$ & $\begin{array}{c}\text { extraterrestre } \\
\text { stade } \\
\text { ours } \\
\text { dentiste }\end{array}$ & rhinocéros & 13 \\
\hline $\int$ & $\begin{array}{l}\text { chocolat } \\
\text { chaussette }\end{array}$ & $\begin{array}{c}\text { machine à laver } \\
\text { fourchette } \\
\text { supermarché }\end{array}$ & & & capuche & 6 \\
\hline $\mathrm{V}$ & $\begin{array}{l}\text { vétérinaire } \\
\text { ventilateur }\end{array}$ & $\begin{array}{c}\text { couverture } \\
\text { machine à laver }\end{array}$ & & $\begin{array}{c}\text { voiture } \\
\text { pieuvre } \\
\text { livre } \\
\text { enveloppe } \\
\text { avion } \\
\end{array}$ & locomotive & 10 \\
\hline $\mathrm{z}$ & zèbre & ciseau & déguisement & & fraise & 4 \\
\hline 3 & jambe & pyjama & & & neige & 3 \\
\hline В & $\begin{array}{c}\text { rhinocéros } \\
\text { robe }\end{array}$ & $\begin{array}{c}\text { extraterrestre } \\
\text { oreiller } \\
\text { parapluie } \\
\text { euro } \\
\text { farine } \\
\text { vétérinaire } \\
\text { aspirateur } \\
\text { aquarium } \\
\text { rhinocéros }\end{array}$ & $\begin{array}{l}\text { ordinateur } \\
\text { fourchette } \\
\text { supermarché } \\
\text { couverture } \\
\text { escargot } \\
\text { couverture } \\
\text { uniforme }\end{array}$ & $\begin{array}{l}\text { crocodile } \\
\text { grenouille } \\
\text { griffe } \\
\text { fraise } \\
\text { zèbre } \\
\text { tigre } \\
\text { pieuvre } \\
\text { ours } \\
\text { livre } \\
\text { extraterrestre }\end{array}$ & $\begin{array}{c}\text { gare } \\
\text { docteur } \\
\text { voiture } \\
\text { vétérinaire } \\
\text { ventilateur } \\
\text { ordinateur } \\
\text { hélicoptère } \\
\text { aspirateur }\end{array}$ & 42 \\
\hline
\end{tabular}




\section{biberon \\ citron \\ yaourt \\ biberon}

\begin{tabular}{|c|c|c|c|c|c|}
\hline $\mathrm{m}$ & $\begin{array}{c}\text { médicament } \\
\text { machine à } \\
\text { laver } \\
\text { menton } \\
\text { main }\end{array}$ & $\begin{array}{l}\text { camion } \\
\text { tomate } \\
\text { supermarché } \\
\text { locomotive } \\
\text { cinéma } \\
\text { pyjama } \\
\text { déguisement } \\
\text { médicament }\end{array}$ & uniforme & $\begin{array}{c}\text { bonhomme } \\
\text { aquarium } \\
\text { hippopotame }\end{array}$ & 17 \\
\hline $\mathrm{n}$ & neige & $\begin{array}{c}\text { rhinocéros } \\
\text { cinéma } \\
\text { uniforme } \\
\text { bonhomme } \\
\text { grenouille } \\
\text { ordinateur } \\
\text { machine à laver } \\
\text { vétérinaire }\end{array}$ & & $\begin{array}{l}\text { farine } \\
\text { téléphone }\end{array}$ & 11 \\
\hline 1 & $\begin{array}{c}\text { locomotive } \\
\text { loup } \\
\text { livre } \\
\text { langue }\end{array}$ & $\begin{array}{c}\text { hélicoptère } \\
\text { éléphant } \\
\text { téléphone } \\
\text { ventilateur } \\
\text { chocolat } \\
\text { machine à laver }\end{array}$ & $\begin{array}{c}\text { ongle } \\
\text { bibliothèque } \\
\text { enveloppe } \\
\text { parapluie }\end{array}$ & $\begin{array}{l}\text { crocodile } \\
\text { huile }\end{array}$ & 16 \\
\hline $\mathrm{n}$ & & & & peigne & 1 \\
\hline $\mathrm{j}$ & yaourt & oreiller & $\begin{array}{l}\text { pieuvre } \\
\text { avion } \\
\text { camion } \\
\text { indien } \\
\text { aquarium }\end{array}$ & grenouille & 8 \\
\hline $\mathrm{W}$ & & & $\begin{array}{c}\text { poisson } \\
\text { voiture } \\
\text { aquarium } \\
\end{array}$ & & 3 \\
\hline $\mathrm{U}$ & huile & & parapluie & & 2 \\
\hline
\end{tabular}

Vowel distribution

$\begin{array}{lll}\text { Word-initial } & \text { Word-final } & \text { Total }\end{array}$


Preliminary version produced by the authors.

Geneviève Meloni, Valérie Schott-Brua, Anne Vilain, Hélène Lœvenbruck, Eulalies Consortium*, et al.. Application of childhood apraxia of speech clinical markers to French-speaking children: A preliminary study. International Journal of Speech-Language Pathology, 2020, 22 (6), pp.683-695. 〈10.1080/17549507.2020.1844799〉. 〈hal-03344800〉

*Consortium EULALIES (alphabetical order): Gillet-Perret, E. (CRTLA, CHUGA), Machart, L. (LPNC-GIPSA-lab), Puissant C. (GIPSA-lab)

\begin{tabular}{|c|c|c|c|}
\hline $\mathrm{a}$ & $\begin{array}{l}\text { aspirateur } \\
\text { aquarium } \\
\text { avion }\end{array}$ & $\begin{array}{l}\text { pyjama } \\
\text { chocolat } \\
\text { cinéma }\end{array}$ & 6 \\
\hline $\mathrm{e}$ & $\begin{array}{l}\text { hélicoptère } \\
\text { éléphant }\end{array}$ & $\begin{array}{c}\text { oreiller } \\
\text { supermarché } \\
\text { machine à laver }\end{array}$ & 5 \\
\hline$\varepsilon$ & $\begin{array}{c}\text { extraterrestre } \\
\text { escargot }\end{array}$ & & 2 \\
\hline$\varnothing$ & euro & & 1 \\
\hline$œ$ & œuf & & 1 \\
\hline o & oreiller & $\begin{array}{c}\text { ciseau } \\
\text { euro } \\
\text { escargot }\end{array}$ & 4 \\
\hline 0 & ordinateur & & 1 \\
\hline $\mathrm{i}$ & hibou & & 1 \\
\hline $\mathrm{u}$ & ours & hibou & 2 \\
\hline $\mathrm{y}$ & uniforme & & 1 \\
\hline$\tilde{\mathrm{a}}$ & enveloppe & $\begin{array}{l}\text { déguisement } \\
\text { éléphant } \\
\text { toboggan } \\
\text { médicament }\end{array}$ & 5 \\
\hline$\tilde{\jmath}$ & ongle & $\begin{array}{l}\text { avion } \\
\text { biberon } \\
\text { camion } \\
\text { citron } \\
\text { menton } \\
\text { poisson }\end{array}$ & 7 \\
\hline$\tilde{\varepsilon}$ & indien & $\begin{array}{c}\text { indien } \\
\text { main }\end{array}$ & 3 \\
\hline
\end{tabular}

